Utah State University

DigitalCommons@USU

$5-1980$

\title{
Notes on the Biology of Halictus (Halictus) farinosus Smith (Hymenoptera: Halictidae)
}

William P. Nye

Utah State University

Follow this and additional works at: https://digitalcommons.usu.edu/piru_pubs

Part of the Entomology Commons

\section{Recommended Citation}

Nye, W. P. 1980. Notes on the Biology of Halictus (Halictus) farinosus Smith (Hymenoptera: Halictidae). USDA ARR-W-11/May 1980.

This Article is brought to you for free and open access by the Pollinating Insects Research Unit at DigitalCommons@USU. It has been accepted for inclusion in All PIRU Publications by an authorized administrator of DigitalCommons@USU. For more information, please contact digitalcommons@usu.edu.

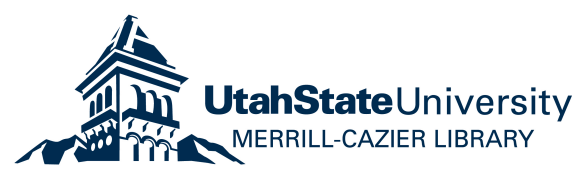




\section{Notes on the Biology of Halictus (Halictus) farinosus Smith (Hymenoptera: Halictidae)}

U.S. Department of Agriculture

Science and Education Administration

igricultural Research Results • ARR-W-11/May 1980 
This publication is available from the Bee Biology and Systematics Laboratory, Natural Resources-Biology Building, UMC 53, Utah State University, Logan, Utah 84322 .

International Standard Serial Number (ISSN) 0193-3817

Science and Education Administration, Agricultural Research Results, Western Series, No. 11, May 1980

Published by Agricultural Research (Western Region), Science and Education Administration, U.S. Department of Agriculture, Oakland, Calif. 94612 


\begin{abstract}
Describes the habitat, life history, foraging, social behavior, and nest architecture of the subsocial halictine bee Hal ictus (Hal ictus) farinosus Smith. The interplay of host-plant conditions with nest development and generations is discussed. Natural enemies and other associates are noted but not extensively treated.

KEYWORDS: halictine bees, Hal ictus farinosus, host plant conditions, nest development, soil-nesting bees.
\end{abstract}

\title{
ACKNOWLEDGMENTS
}

I thank G. E. Bohart, Utah State University, and R. W. Thorp, University of California, Davis, for providing critical comments on the manuscript. 


\section{CONTENTS}

Page

Introduction............................. 1

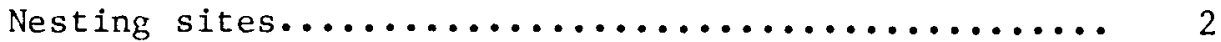

Soils conditions and vegetative cover............. 2

Seasonal activity........................ 3

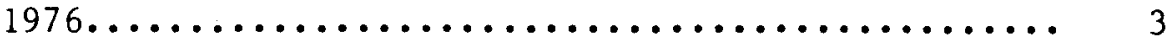

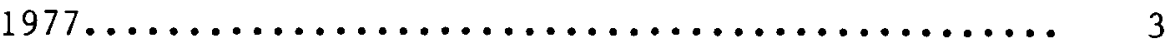

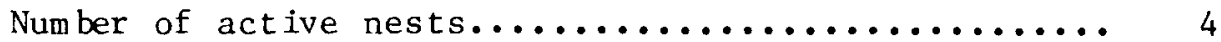

Foraging.............................. 5

Pollen identification...................... 5

Markings of foragers....................... 10

Flight activity......................... 10

Jest architecture........................ 12

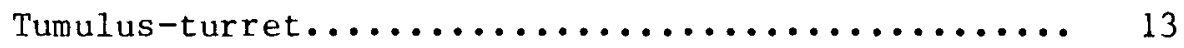

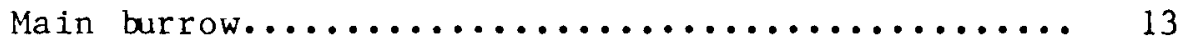

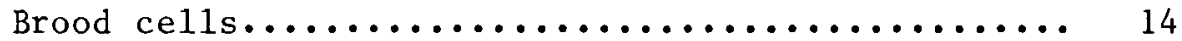

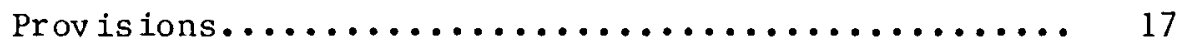

Egg-to-adult development.................... 17

Dormancy and hibernation..................... 19

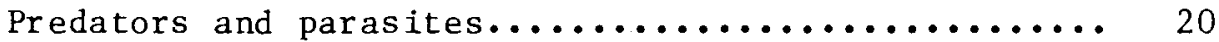

Discussion.............................. 23

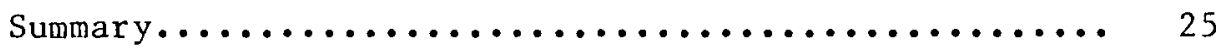

Literature cited........................ 26

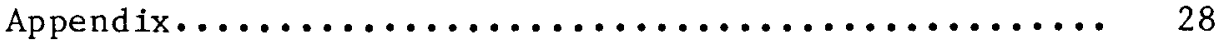

Key to symbols used in illustrations............ 28

Glossary............................. 28 


\title{
NOTES ON THE BIOLOGY OF HALICTUS (BALICTUS) FARINOSUS SMITH
}

\author{
(HYMENOPTERA: HALICTIDAE) \\ By William P. Nye ${ }^{1}$
}

\section{INTRODUCTION}

Hal ictus Latreille is a genus of subsocial, soil-nesting, halictine bees. The subfamily is characterized by the strongly bent basal vein of the forewing and the linear, longitudinal pseudopygidium of the sixth tergum of the females. The genus Hal ictus has apical hair bands $\mathrm{n}$ the abdominal terga. Hal ictus farinosus Smith is nonmetallic (no blue or green coloring), 12 to $14 \mathrm{~mm}$ in length, and has apical bands of golden-yellow pubescence on the abdominal terga. Ha1 ictus parallel us Say is a closely related species with a more easterly distribution in North America. It is readily distinguished from $H$. farinosus by its yellowish wings with infumate (smoky colored) apices.

H. farinosus, as reported by Sandhouse (1941), ${ }^{2}$ extends from New Mexico west to California and north to British Columbia and Montana. Sandhouse examined specimens from New Mexico, Colorado, Arizona, Utah, Idaho, Montana, Nevada, California, Washington, and British

${ }^{1}$ Research entomologist, retired, Bee Biology and Systematics Laboratory, Utah State University, Logan.

2 The year in italic, when it follows the author(s)' name, refers to iterature Cited, p. 26.
Columbia and found that the species exhibited practically no variation. Hal ictus farinósus replaces $H$. parallelus in the States or portions of States west of the Continental Divide. On July 21, 1965, G. E. Bohart and $P$. F. Tor chio (personal communication) collected $H$. parallel us at Shoshoni, Fremont Co., Wyo., located barely east of the Continenta1 Divide.

No special biological studies have been published on Hal ictus (Halictus) farinosus Smith, but G. E. Bohart (1952) published a diagram of a nest of $H$. farinosus and Stephen et a1. (1979) commented briefly on its biology. Roberts (1973) provided biological data on several species of Hal ictus. Distributional records (with implied habitat information) and host plant and flight data are contained in several taxonomic papers by Ashmead (1903), Crawford (1902), Roberts (1973), Robertson (1928), and Vachal (1904).

Biological studies have been published on H. (Hal ictus) 1 igatus Say by Chandler (1955), Kirkton (1968), Litte (1977), and Michener and Bennett (1977). A brief note was published on $H$. parallel us Say by Hungerford and Williams (1912). 


\section{NESTING SITES}

Hal ictus farinosus nests in dry mesic canyons in mountainous regions, on scattered grass and brush-covered slopes, or in open woodlands. The nests may be singly or gregariously situated, a result of site utilization rather than any benefits derived from such groupings.

My study area was located in Green Canyon, Cache Co., Utah, approximately 3,200 m northeast of the Utah State University campus in Logan. The following four Green Canyon sites were studied:

Site $1 .--800 \mathrm{~m}$ east of the Cache National Forest (CNF) boundary line on an "island" about $1.5 \mathrm{~m}$ wide and $25 \mathrm{~m}$ long in the middle of the roadway and on both sides of the road.

Site 2.--Approximate1y 1,100 m up the canyon from the CNF boundary line on the north side of the road in an area about 10 by $22 \mathrm{~m}$.

Site 3.--1,600 m up the canyon from the CNF boundary line on a narrow slope about 2 to $3 \mathrm{~m}$ wide and $30 \mathrm{~m}$ long between the road and the dry wash. The nest area sloped from $5^{\circ}$ to $15^{\circ}$ in a southerly direction (fig. 1).

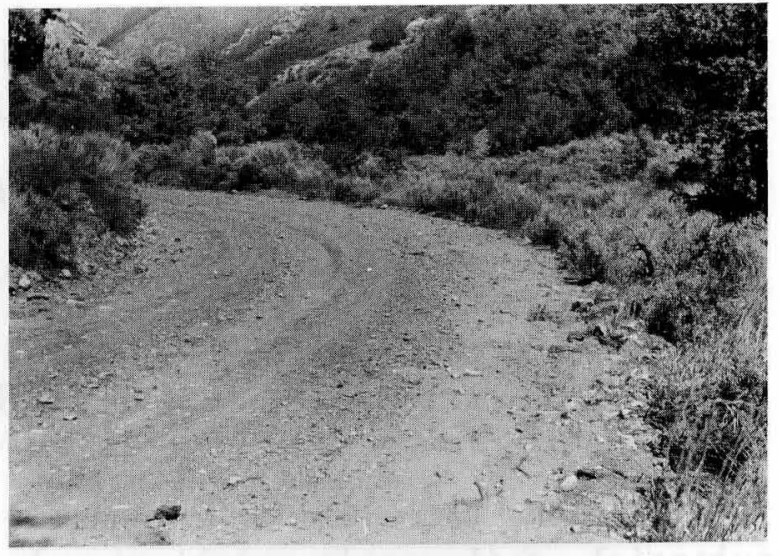

Figure 1.--Nesting site 3 on a narrow grass-covered slope between the road and the dry wash. Green Canyon, Utah.

Site 4.--2,400 m up the canyon from the CNF boundary line on the eastern edge of the road and along the hard packed trails, an area of approximately 40 by $60 \mathrm{~m}$.

\section{SOILS CONDITIONS AND VEGETATIVE COVER}

The soil at the four nesting sites was classified as Millville Silt Loam. The physical characteristics of the soil from the nesting sites in Green Canyon were analyzed as follows: fine to very fine sand, 37 percent; silt, 50 percent; clay, 13 percent; $\mathrm{pH}, 8.1$. The humus content seemed to be low, except in the top 7 to $10 \mathrm{~cm}$ where plant roots were abundant. The soil, when dry, was light gray-brown to a depth of approximately $60 \mathrm{~cm}$. In general, the soil was hard and quite rocky, except at site 2, which had very few rocks. When moist, the soil was darker in color, easier to manipulate, but also more likely to crumble and ruin cells in the nest dissection. The surface did not crack when dry, but when distur bed, formed a fine dust. During rains, the water was rapid1y absor bed. The only large cavities in the soil were those made by bees, ants, tiger beetle larvae, and root decomposition. The bees seemed to prefer rather dry, compact, and we11-drained soil along roadsides and trails sparsely covered with short vegetation.

During the study, most of the soil surface in the four nesting 
ites was covered with sparse growth of crested wheatgrass (Agropyron cristatum (L.) Gaertn.), scattered gum plant

(Grindel ia squarrosa (Pursh) Dunal), and Gray's lomatium (Lomatium grayi (Coult. \& Rose) Coult. \& Rose). The edges of roads, trails, and trampled or partially denuded areas favored the establish- ment of nests. Since the vegetation was low and sparse, the nests received very little shading during the early part of the day. Many nests established in the spring were hidden by vegetation as the plants grew taller, partially shading the nest by midsummer.

\section{SEASONAL ACTIVITY}

\section{6}

In 1976, the first overwintering females (queens) of Hal ictus farinosus emerged from hibernation on April lst and continued emerging until early May. During this period, the bees visited Lomatium grayi for nectar and pollen, and each individual dug a separate (25 to $45 \mathrm{~cm}$ deep) main burrow. They remained in the completed burrows ( 25 to $45 \mathrm{~cm}$ deep) for a number of days without further activity. The first brood cells were constructed in late May and early June, 10 to $15 \mathrm{~cm}$ below the surface. In guarding the nest, the bee faced the nest entrance. She usually assumed the guard position in dim light about 10 to $15 \mathrm{~mm}$ below the entrance of the main burrow. From this position, she could effectively block the entrance with her body and repel any intruder, including the small Leucophora flies (fig. 2).

The first progeny (a11 females) appeared as adults in late June and early July and became active as workers in the parental nests. As workers, they enlarged the nest, constructed and provisioned cells, and fashioned pollen ba11s on which the queen laid eggs.

The marked overwintering queens were last seen flying on July 28, overlapping the flight period of the first female progeny by 2 to 3 weeks. The first female progeny flew for a shorter Deriod than the overwintering queens (disappearing about August 12).
The second female progeny began flying early in August and were last seen flying and taking nectar from rabbit brush on September 15. These females were not seen to provision any cells but left the nesting area to void wastes, feed, mate, and hibernate. I observed several successful matings on flowers of rabbit brush.

The first male bees were seen flying in late July, and the last were seen flying and taking nectar from rabbit brush on September 25 . Male pupae were found in all nests after the emergence of the firstgeneration females.

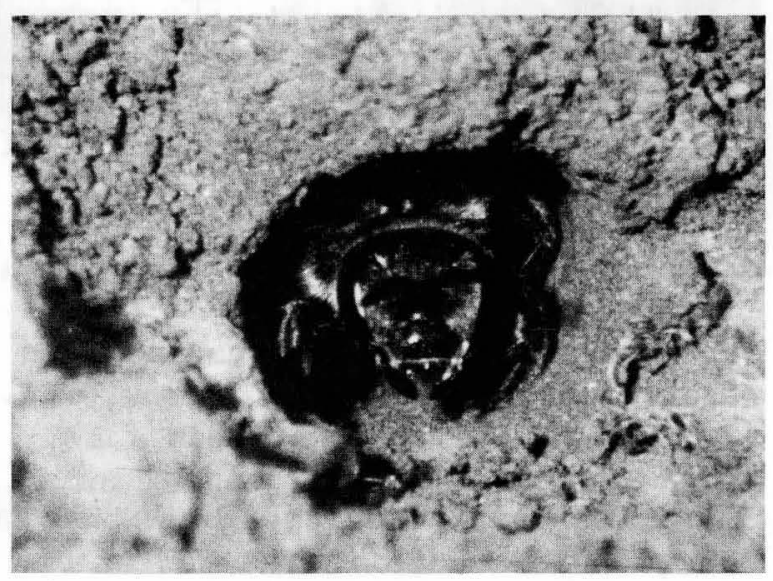

Figure 2.--H. farinosus guarding nest entrance.

\section{7}

In 1977, the first observed overwintering female bee emerged from 
hibernation on April 8, one week later than in 1976. Overwintering females continued to emerge until late May. The first progeny appeared on July 8 and became active as workers in the parental nests. The marked overwintering queens were last seen flying in early August, overlapping the flight period of the first female progeny by 2 to 3 weeks. The first female progeny constructed and provisioned cells and laid some eggs until August 20 (about 2 weeks later than in 1976). The second generation females began flying in midAugust and were last seen flying the taking nectar on Septermber 26.
Males were first seen flying in early August and last seen flying and ( taking nectar on October 5 .

The social structure became evident as the first female progeny emerged and became active as workers in the parental nest. The queen remained in the nest, acting as nest guard and primary egg layer; however, when the queen began to fail (or died), one of the workers took over as guard and primary egg layer. Since she had no access to males, all of her progeny were male.

\section{NUMBER OF ACTIVE NESTS}

The number of active nests was greatest during May when overwintering females were returning to the nesting sites and digging their main burrows. The number of active nests by month and year at site 1 was as follows:

$\begin{array}{lrr}\text { Date } & 1976 & 1977 \\ \text { May 15 } & 368 & 383 \\ \text { June 15 } & 98 & 225 \\ \text { July 15 } & 81 & 158 \\ \text { Aug. 15 } & 62 & 93\end{array}$

The rapid decline in the number of active nests in June 1976, as compared with 1977, may have resulted from the capture of a large number of female bees for the establishment of a nesting population at the Greenville Experimental Farm in North Logan, Utah.

Some overwintering females died after digging their main burrow ( $f i g$. 3 ). Others died before their first brood emerged, and the progeny abandoned the nest after emerging. In general, the decrease in the number of active nests was similar at each nesting site.

Figure 3.--Newly established spring nest with mainburrow well below cell level with tumulus closing of burrow. June 1, 1977.

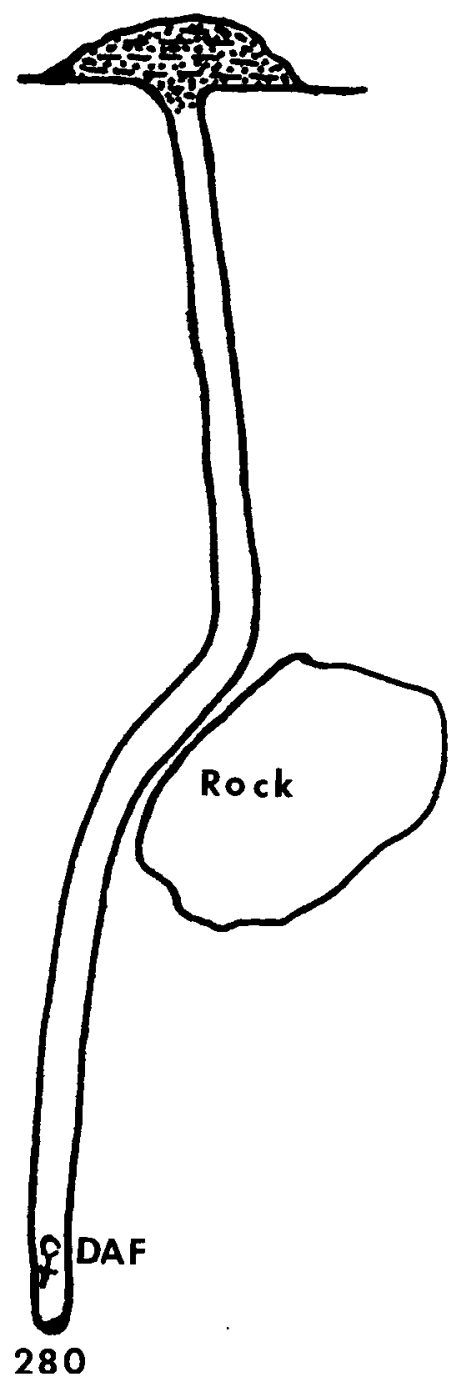


Hal ictus farinosus is a polylectic species with a wide host range throughout the seasonal flight period. The species has been collected from many native and cultivated plants from April to October. Flowers visited were entomophilus annual, biennial, and perennial for bs with a lesser number of flowering shrubs and trees being frequented. Table 1 lists the activities of $H$. farinosus males and females on 43 plant species from 14 families on which they have been collected. Bohart and Nye (1960) found $H$. farinosus to be an important pollinator of carrots during the blooming period (fig. 4). Bohart et al. (1979) found H. farinosus to be an important pollinator of onions. Mel itus alba Desr. and Medicago sativa L. (both legumes) were important sources of pollen and nectar (figs. 5 and 6 ).

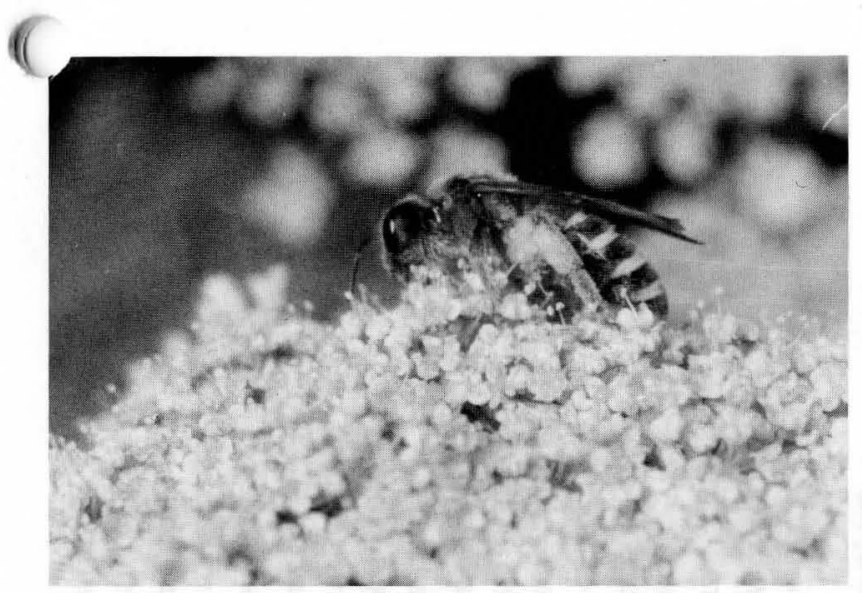

Figure 4.-- H. farinosus collecting pollen from carrot (Daucus carota).

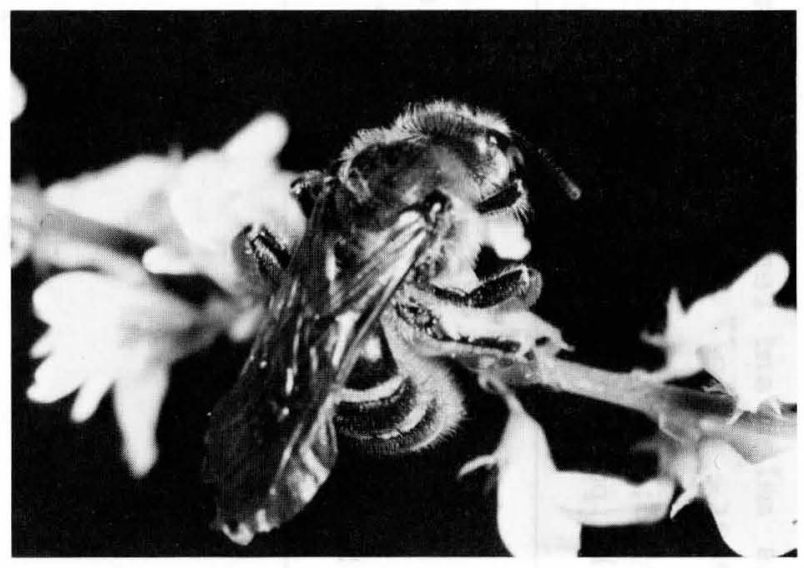

Figure 5.--H. farinosus collecting pollen from white sweet clover (Mel il otus alba).

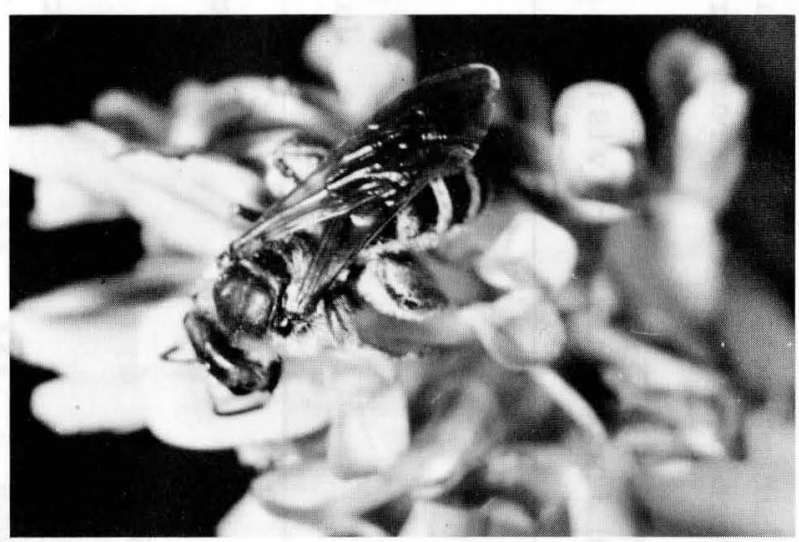

Figure 6.--H. farinosus collecting pollen from alfalfa (Medicago sativa).

\section{POLLEN IDENTIFICATION}

The identification of pollens in pollen balls dissected from nests during the solitary and social nesting stages revealed that the bees collected pollen from two to seven different pecies of plants to provision one el1.
In 1976, when many species of plants were blooming, pollen balls examined contained pollen from an average of 3.18 different species of plants during the solitary nesting stage and 4.1 different species during the social nesting stage. Exam- 
Table 1.--Pollen and nectar gathering activity of Halictus farinosus males and females on plants in bloom in Green Canyon, Utah, from April to October, 1976-77

[x, present during 10-day period; $x x$, present during 20-day period; xxx, present during 30-day period; + , visited uncommonly; ++ , visited commonly; $P$, pollen; $N$, nectar]

\begin{tabular}{|c|c|c|c|c|c|c|c|c|c|c|c|c|}
\hline \multirow[b]{2}{*}{ Family } & \multirow[b]{2}{*}{$\begin{array}{l}\text { Species and } \\
\text { common names }\end{array}$} & \multirow[b]{2}{*}{ Apr. } & \multirow[b]{2}{*}{ May } & \multirow[b]{2}{*}{ June } & \multirow[b]{2}{*}{ July } & \multirow[b]{2}{*}{ Aug. } & \multirow[b]{2}{*}{ Sept. } & \multirow[b]{2}{*}{ Oct. } & \multirow{2}{*}{$\begin{array}{l}\text { Other } \\
\text { bees }\end{array}$} & \multicolumn{3}{|c|}{$\begin{array}{l}\text { Harinosus } \\
\text { foragers }\end{array}$} \\
\hline & & & & & & & & & & 8. & $q \mathrm{P}$ & $\oint \mathrm{N}$ \\
\hline \multirow[t]{11}{*}{ Asteraceae } & $\begin{array}{l}\text { Achillea mill efol ium L. } \\
\quad \text { Yarrow }\end{array}$ & & & $\mathrm{x}$ & $\operatorname{xxx}$ & $x x x$ & & & ++ & + & + & + \\
\hline & $\begin{array}{l}\text { Agoseris glauca (Pursh) Raf. } \\
\text { Mountain dandelion }\end{array}$ & & $\mathrm{xxx}$ & $x x$ & & & & & + & & + & \\
\hline & $\begin{array}{l}\text { Aster canescens Pursh } \\
\text { Hoary aster }\end{array}$ & & & & $\mathrm{xxx}$ & $\mathrm{xxx}$ & $\mathrm{xxx}$ & , & + & + & + & \\
\hline & $\begin{array}{l}\text { Bal samorhiza sagittata } \\
\text { (Pursh) Nuff } \\
\text { Balsamroof } \\
\text { Chrysothamnus nauseosus }\end{array}$ & & $x \times x$ & $x$ & & & & & & & + & + \\
\hline & $\begin{array}{l}\text { (Pa11) Britton } \\
\text { Rabbitbrush }\end{array}$ & & & & & $x \times x$ & $\mathrm{xxx}$ & $\mathrm{x}$ & ++ & ++ & ++ & $H$ \\
\hline & $\begin{array}{l}\text { Circium fol iosum (Hook) DC } \\
\text { Elk thistle }\end{array}$ & & $\mathrm{xxx}$ & $\mathrm{xxx}$ & $\mathrm{xxx}$ & $\mathrm{xxx}$ & $\mathrm{x}$ & & $+t$ & + & + & \\
\hline & $\begin{array}{l}\text { Crepis acumminata Nutt. } \\
\text { Long-leaved hawks beard }\end{array}$ & & $x \times x$ & $\mathrm{xxx}$ & $x \times x$ & $x x$ & & & + & + & + & \\
\hline & $\begin{array}{l}\text { C. occidental is Nutt. } \\
\text { Western hawks beard }\end{array}$ & & $x x x$ & $\mathrm{xxx}$ & $\mathrm{xxx}$ & & & & + & & + & \\
\hline & $\begin{array}{l}\text { Erigeron pumil us lutt. } \\
\text { Hairy fleabane daisy } \\
\text { Grindel ia squarrosa }\end{array}$ & $\mathrm{x}$ & $\mathrm{xxx}$ & $\mathrm{xxx}$ & $\mathrm{xxx}$ & $\mathrm{xxx}$ & $\mathrm{xxx}$ & & ++ & + & + & \\
\hline & $\begin{array}{l}\text { (Pursh) Dunal. } \\
\text { Gumplant }\end{array}$ & & & & $\mathrm{xxx}$ & $\mathrm{xxx}$ & $\mathrm{xxx}$ & & + & + & $H$ & + \\
\hline & $\begin{array}{l}\text { Gutierrezia sarothrae } \\
\text { (Pursh) Britton \& Rusby } \\
\text { Broom snakewood }\end{array}$ & & $x x$ & $\mathrm{xxx}$ & $x \times x$ & $\mathrm{xxx}$ & $x \times x$ & $\mathrm{x}$ & + & + & ++ & \\
\hline
\end{tabular}


(Nutt.) Torr. \& Gray

Little sunflower

Rudbeckia occidental is Nutt. Western coneflower

Senecio spp.

Butterweed

Sol idago canadens is L. Goldenrod

Taraxacum officinale Weber Dande1ion

Tragopogon dubius Scop. Salsify

Viguiera multiflora

(Nutt.) Blake

Goldeneye

Wyethia ampleyicanl is

(Nutt.) Nutt.

Mule ears

Um be11i-

ferae

Rosaceae
Lomatium dissectum

(Nutt.) Mathias/Constance

Wild carrot

$\mathrm{xxx}$

L. grayi (Coult. \& Rose)

Coult. \& Rose

Gray's Iomatium

Orogenia I inearifol ia

S. Wats.

Indian parsnip

Daucus carota L.

subsp. carota

Wild carrot

Cercocarpus ledifol ius Nutt.

Curlleaf mahogany

Petrophytum caespitosum

(Nutt.) Rydb.

Tufted rockmat

$\mathrm{xxx}$ $\mathrm{xx}$

$\mathrm{xxx}$

$\mathrm{xx}$

$+$

$+$

$\mathrm{xxx}$

$+$

$+$

$\mathrm{xxx} \quad \mathrm{xx}$

$+$

$+$

$\mathrm{xxx} \quad \mathrm{xxx} \quad \mathrm{xxx} \quad \mathrm{x}$

$++t+t$

$\mathrm{xxX}$

$\mathrm{xxx} \quad \mathrm{xxx}$

$+$

$+$

$\mathrm{xx} \quad \mathrm{xxx}$

$+\quad+$

$\mathrm{xxx} \quad \mathrm{xxx} \quad \mathrm{xxx}$

$\mathrm{xxx} \quad \mathrm{xxx}$

$\mathrm{xxx}$

$\mathrm{xxx} \quad \mathrm{x}$

$\mathrm{xxx} \quad \mathrm{xxx} \quad \mathrm{xxx}$

$++t+$

$++t$

$+$

$+++$

$+$

$++1$

$+$

$+$

$\mathbf{X}$

$\mathrm{xxx}$

$\mathrm{XX}$

$\mathrm{xx}$

$\operatorname{xxx}$

$\mathrm{XXX}$

$\mathrm{XXX}$ 
Table 1.--Pollen and nectar gathering activity of Halictus farinosus males and females on plants in bloom in Green Canyon, Utah, from April to October, 1976-77--Continued

[x, present during 10-day period; $x x$, present during 20-day period; xxx, present during 30-day period; + , visited uncommonly; + , visited commonly; $P$, pollen; $N$, nectar ]

Liliaceae

Ranunucu-

laceae

Aceraceae

Convolvulaceae Cucur bitaceae
Species and common names
Apr. May June July Aug. Sept. Oct.
H. farinosus foragers

bees $\frac{}{\delta \quad \text { o }} \mathrm{P} \quad \mathrm{qN}$

Prunus virginiana L.

Chokecherry

Malus pumila Mill. Medicago sativa L.

Alfalfa

Mel il otus al ba Desr.

White sweetclover

$M$. officinal is L.

Yellow sweetclover

All ium cepa L.

$$
\text { Onion }
$$

A. acuminatum Hook Brandegee onion

$z$ igadenus paniculatus

S. Wats.

Deat hcamas

Del phinium nel soni Greene

Low larkspur

Ranunucul us ionis A. Nels. $\mathrm{xxx}$ Sagebrush buttercup

Acer grandidentatum Nutt. Bigtooth maple

Convolvul us arvensis $\mathrm{L}$. Morning glory

Cucurbita pepo L.

Squash

$\begin{array}{llll}+ & & + & + \\ + & & + & + \\ + & & + & + \\ + & + & + & + \\ + & + & + & + \\ + & & + & + \\ + & & + & \\ + & & + & \\ + & & + \\ + & & & \\ + & & & \end{array}$


Hydr op hy 1laceae

Menthaceae

Portulacea

Saxifray-

aceae

Violaceae
Phacel ia hastata Dougl. Silver leaf phacelia Marrubium vulgare L. Horehound

Claytonia lanceolata Pursh Western spring beauty

Ribes peteolare Dougl. Western black current

Viola purpurea Kellogg Yellow mountain violet $\operatorname{xxx} \quad \mathrm{xxx}$

$\operatorname{xxx}$

$\mathrm{xxx}$

$\operatorname{xxx}$

$\operatorname{xxx}$

$\mathrm{xxx}$

$\mathrm{xxx}$

$\mathrm{xx}$

$\mathrm{xxx}$

$\mathrm{xxx}$

$\begin{array}{rrrr} & + & + & + \\ + & + & ++ & + \\ & & + \\ + & & + \\ + & & +\end{array}$


ples: On June 9, during the solitary nesting stage, one pollen ball examined contained pollen from Balsamorhiza sagittata (Pursh) Nutt., 20.33 percent; Lomatium grayi, 59.34 percent; Phacelia hastata Doug1., 20.33 percent; and one examined during the social nesting stage on July 9 contained pollen from B. sagittata, 28.43 percent; Mel il otus al ba, 3.93 percent; $P$. hastata, 55.88 percent; and Taraxacum officinale Weber, 11.76 percent.

In 1977, fewer species of plants bloomed than in 1976, and pollen balls examined contained pollen from an average of 2.95 different species of plants during the solitary nesting stage and 2.1 different species during the social nesting stage. Examples: On June 14, one pollen ball examined during the solitary nesting stage contained pollen from Bal samorhiza sagittata, 71.99 percent; and Prunus virginiana L., 28.01 percent; one examined during the social nesting stage on July 12 contained pollen from $B$. sagittata, 19.05 percent; and $P$. virginiana, 80.95 percent.

\section{MARKINGS OF FORAGERS}

The duration of individual foraging trips as well as the number of bees flying from marked nests was studied by marking the bees and clocking their arrivals and departures at the nest entrances. Most of the bees in the viewing area were marked on the dorsum of the thorax, using butyrate dope paint and small, numbered disks. The disks were cemented onto the dorsum of the thorax with stiff shellac. A 3-inch screen cone with a 2-dr vial inserted in the small end was placed over the nest entrance to bar exit of emerging bees and to prevent entrance by returning bees. Exiting bees trapped in the cones were transferred to a holder for marking and release. The returning bees were netted, transferred to the holder, marked, and released. The holder was a plastic tube $3 \mathrm{~cm}$ in diameter and $7 \mathrm{~cm}$ long with $3-$ by $4-\mathrm{mm}$ mesh cloth netting stretched across one end and a sponge plastic-covered cork plunger to press the bee against the netting for marking. The bee was then marked through the netting. Most of the marked bees returned to the nest in 5 to 30 minutes. A few of the marked bees were never seen again and may have been injured during marking (

The overwintering females were marked with orange paint or disks, and the workers were marked with yellow paint. The plastic disks for marking honey bees were found to be a bit too large for $H$. farinosus and were used only in 1976. The dope paint and the small numbered paper disks $(1.5 \mathrm{~mm})$ were the most successful means of marking.

Before discontinuing the use of the plastic disks, I was successful in marking the overwintering females in six nests during the solitary nesting phase and all of the individuals in three nests during the social nesting phase.

\section{FLIGHT ACTIVITY}

The duration of foraging trips during the solitary nesting stage is illustrated in table 2 for data obtained during a 2-day period for 13 nests in 1977. The average duration per trip to collect a load of pollen was 131 
( able 2.--Flight activity of $\mathrm{H}$. farinosus during sol itary nesting from 13 nests in viewing area, Green Canyon, Utah, June 23-24, 1977

$\begin{array}{llcl}\text { Exit } & \text { Return } & \text { Trip in } \\ \text { Date } & \text { Nime } & \text { time } & \text { minutes }\end{array} \quad$ Other activity

June $23 \quad 1$

$\begin{array}{rrrr}2 & 1510 & 1700 & 110 \\ 3 & 1555 & 1730 & 95 \\ 4 & 1030 & 1405 & 155 \\ & 1615 & 1730 & 75 \\ 5 & 1410 & 1545 & 95 \\ 6 & & & \\ 7 & & & \\ 8 & & & \\ 9 & & & \\ 10 & & & \\ 11 & 1045 & 1345 & 180 \\ 12 & 1100 & 1455 & 235 \\ 13 & 1005 & 1305 & 180 \\ 1 & & & \end{array}$

$\begin{array}{rrrr}2 & & & \\ 3 & & & \\ 4 & & & \\ 5 & & & \\ 6 & 1000 & 1200 & 120 \\ & 1335 & 1520 & 105 \\ 7 & & & \\ 8 & & & \\ 9 & & & \\ 10 & & & \\ 11 & 1000 & 1145 & 105 \\ 12 & 1300 & 1315 & 15 \\ 13 & 1055 & 1450 & 235\end{array}$

Guarding, digging, and sweeping entrance clean.

Pollen gathering.

Do.

Do.

Do.

Do.

Do.

Do.

Guarding.

Do.

Do.

Pollen gathering.

Do.

Do.

Guarding and sweeping entrance clean.

Guarding.

Do.

Do.

Do.

Pollen gathering. Do.

No activity

Do.

Do.

Do.

Pollen gathering.

No pollen gathering.

Pollen gathering.

No activity.

${ }^{1}$ Average time per trip was $131 \mathrm{~min}$.

min with a range of 75 to 235 min per trip.

In 1976, the duration of foraging trips for a 2-day period during the social nesting stage is shown in table
3. The average duration per trip was $118 \mathrm{~min}$ with a range of 65 to $152 \mathrm{~min}$ per trip.

At the Greenville Experimental Farm, $1860 \mathrm{~m}$ west of nesting site 1 , 
Table 3.--Flight of Halictus farinosus during social nesting stage at nest 11 ( site 3, Green Canyon, Utah, July 20-21, 1976

\begin{tabular}{lllccc} 
Date & $\begin{array}{l}\text { Bee } \\
\text { No. }\end{array}$ & $\begin{array}{l}\text { Exit } \\
\text { time }\end{array}$ & $\begin{array}{c}\text { Return } \\
\text { time }\end{array}$ & $\begin{array}{c}\text { Trip in } \\
\text { minutes }\end{array}$ & Activity \\
\hline \multirow{2}{*}{ Ju1y 20} & 1 & 0920 & 1149 & 149 & Pollen gathering. \\
& 1 & 1210 & 1430 & 140 & Do. \\
& 3 & 1245 & 1350 & 65 & Do. \\
& 2 & 1245 & 1400 & 75 & Do. \\
& 1 & 1445 & 1715 & 150 & Do. \\
& 2 & 1620 & 1750 & 90 & Do. \\
& 2 & 0920 & 1148 & 148 & Do. \\
& 2 & 1158 & 1430 & 152 & Do. \\
& 2 & 1447 & 1607 & 80 & Do.
\end{tabular}

${ }^{1}$ Average time per trip was 118 minutes.

a marked bee was observed collecting pollen from onion umbels for $3-1 / 2 \mathrm{~min}$, visiting 23 umbels before she disappeared from sight. During that time, she collected about one-fifth or less of a load of pollen. In Green Canyon, $2050 \mathrm{~m}$ up the canyon from nesting site 4, a marked bee was observed collecting pollen from goldeneye (Viguiera multiflora (Nutt.) Blake) for $3 \mathrm{~min}$, visiting 41 flowers before she disappeared from sight (fig. 7). She collected about the same amount of pollen as did the one observed on onions. Based on these and other observations, a bee could collect a load of pollen in 15 to $18 \mathrm{~min}$; however, several bees were observed grooming themselves, and resting on flowers and leaves, and collecting nectar to sustain themselves during the long foraging trips before returning to the nest.

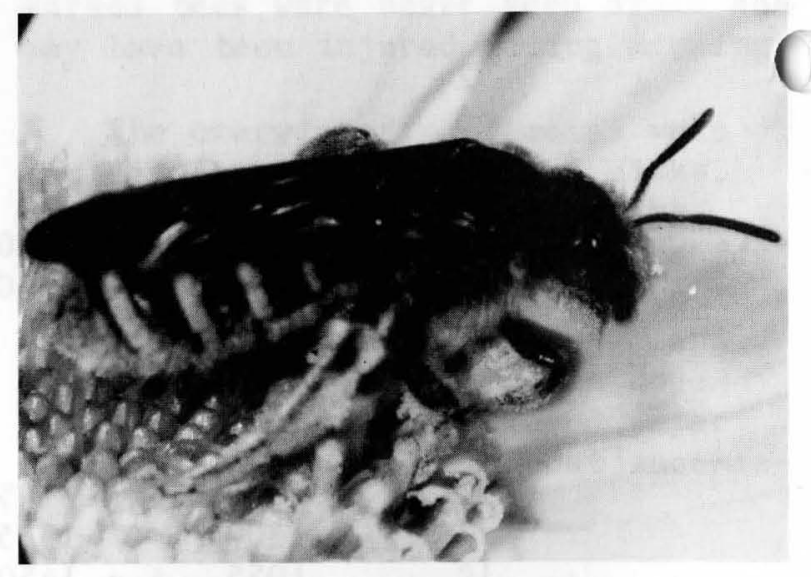

Figure 7.--H. farinosus collecting pollen from goldeneye (Viguiera mul $t$ ifl ora).

\section{NEST ARCHITECTURE}

The Hal ictus farinosus nest pattern with its vertical main burrow and short horizontal laterals, each subtending a single horizontal cell, is similar to that of most other halictines. The cell cap is composed of a series of concentric spiral rings of soil visible on the inside of the cell cap but smooth and flush with the main burrow wall.

The following description is based ol. 
( ) bservations of nests built by overwintering queen bees in the Green Canyon.

\section{Tumulus-Turret}

The main burrow was started late in the afternoon and evening. As the bee excavated her main burrow, she pushed up a symmetrical tumulus about 6 to $8 \mathrm{~cm}$ in diameter and 2 to $3 \mathrm{~cm}$ high around the entrance. She backed up the burrow, pushing moist soil, but did not expose her abdomen by clearing or tamping at this time. She then constructed a curved turret under the tumulus that acted as a horizontal passage leading from the actual burrow entrance to the edge of the tumulus. The lateral tunnel and burrow was always left open. She excavated a trail in front of the tumulus and kept it swept clean (fig. 8). A similar tumulus-turret is formed by Nomia triangul ifera Vachal, except that this species always plugs the entrance when it leaves or enters the nest.

The tumulus-turret is easily washed away by rain or blown away by the wind. By midseason or before, it is usually gone. Figure 9 shows the bee cleaning the nest entrance after rain had washed away the tumulusturret. The entrance to the vertical main burrow is circular and about $9 \mathrm{~mm}$ in diameter.

\section{Main Burrow}

The vertical main burrow excavated by the overwintering queen was about 10 or $11 \mathrm{~mm}$ in diameter, but it narrowed toward the entrance and extended in depth from 25 to $30 \mathrm{~cm}$, well below the cell level of the solitary nesting stage. The development of the nest during the solitary nesting phase is

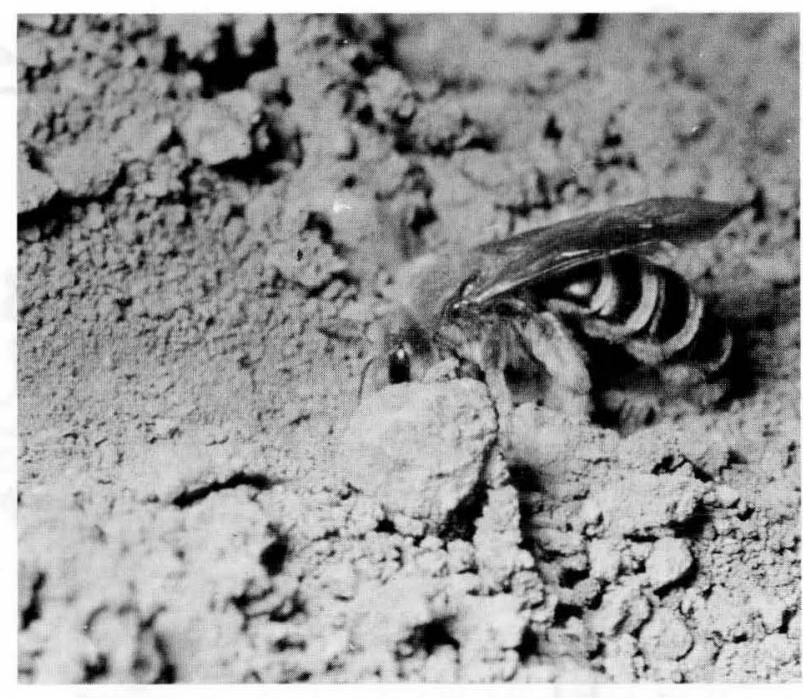

Figure 8.--H. farinosus sweeping trail in front of nest entrance.

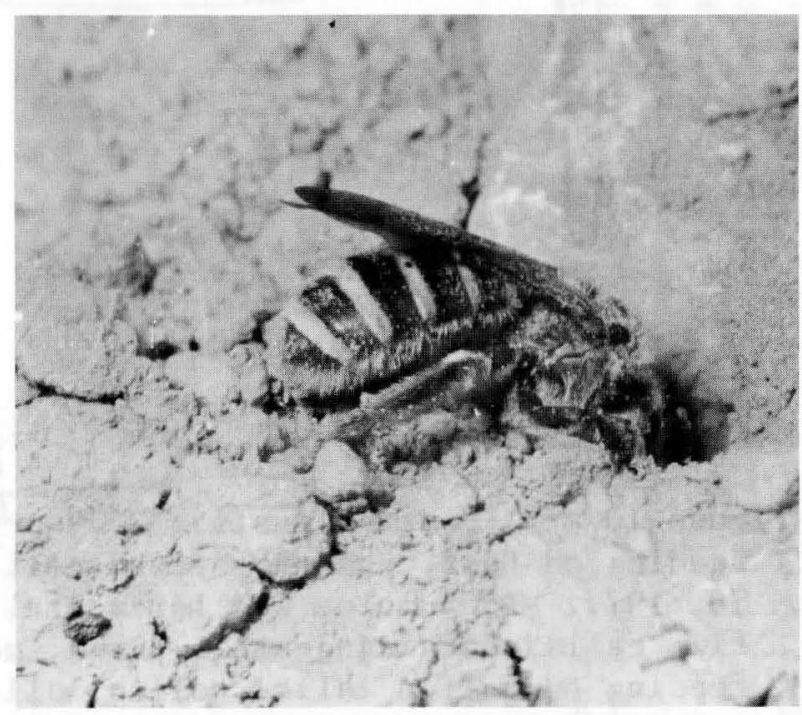

Figure 9.--H. farinosus cleaning nest entrance after rain washed away the tumulus-turret.

illustrated in figure $10 \mathrm{~A}-\mathrm{C}$. The burrow wall was smoothed and had no apparent lining.

During the social nesting stage, the main burrow was extended by the workers to depths of $40 \mathrm{~cm}$ or more. The development of the nest during the social nesting phase is illustrated in figure $11 A-D$. 

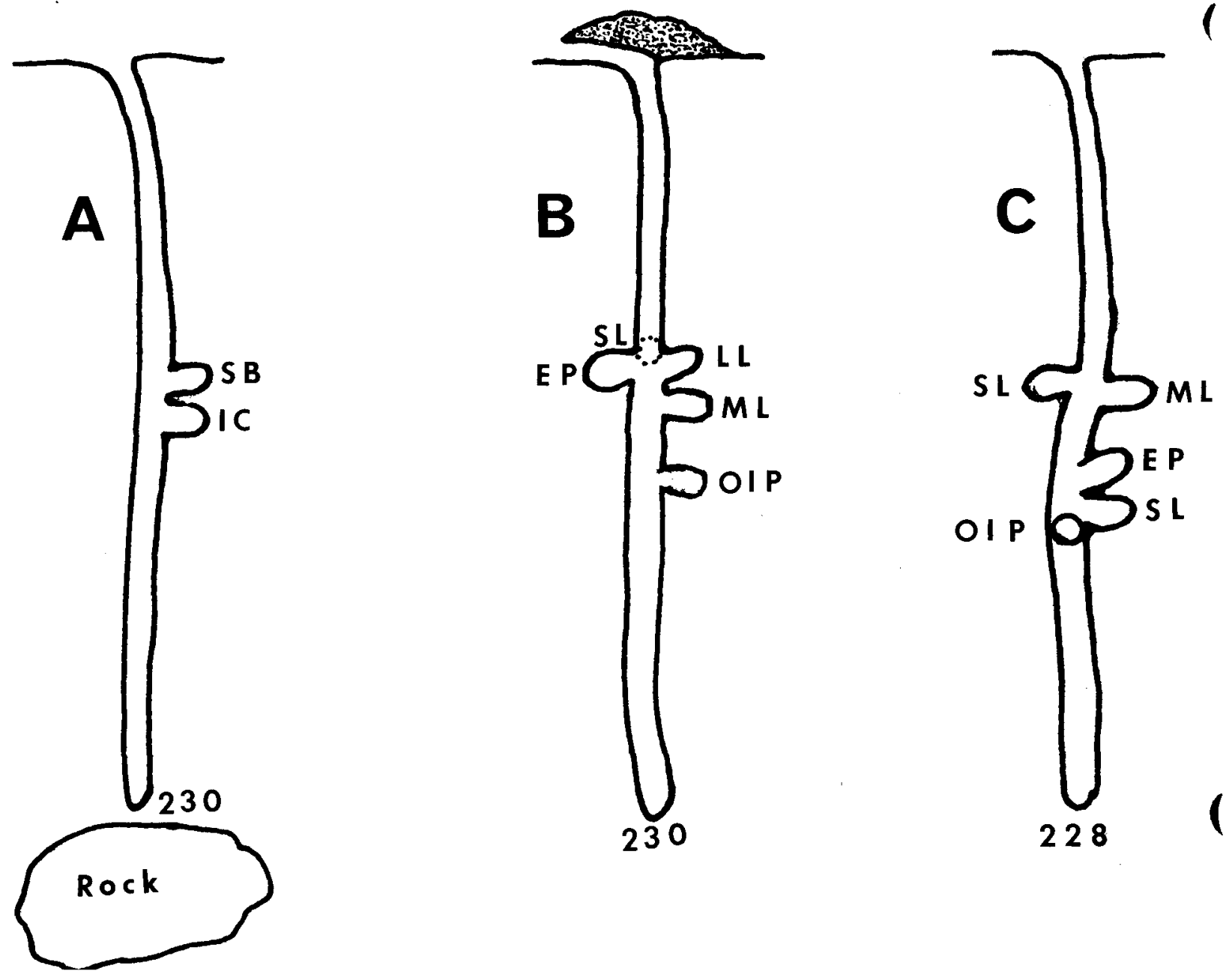

Figure 10 A-C.--Active nests: $A$, Two cells, one with small bombyliid larva feeding on host, and the second cell under construction and incomplete. June 16, 1977. $B$, Tumulus and horizontal entrance to main burrow still intact with five cells containing small larva, medium-sized larva, and large larva all feeding on pollen balls, pollen ball and egg, and open cell with incomplete provisions. June 16, 1977. C, Five cells, two with small larva, one with medium-sized larva, pollen ball and egg, and open cell with incomplete provisions. June 16, 1977.

\section{Brood Cells}

The first brood cells constructed by the queen bee during the solitary nesting stage were positioned 10 to 15 $\mathrm{cm}$ below the surface (fig. 12). Dissection of a nest during the solitary nesting stage is shown in figure 13. It shows a female pupa, two prepupae (the one on the left with a second stage bombyliid larva feeding on the host), and a second instar larva feeding on a pollen bal1. Figure 14 shows an early third instar larva on a pollen ball in the cell.

Each cell was horizontal, oval in shape, arched at the maximum width, and flattened on the lower side. The entrance cap, which abutted the main burrow, was 3 to $5 \mathrm{~mm}$ thick. The cell 

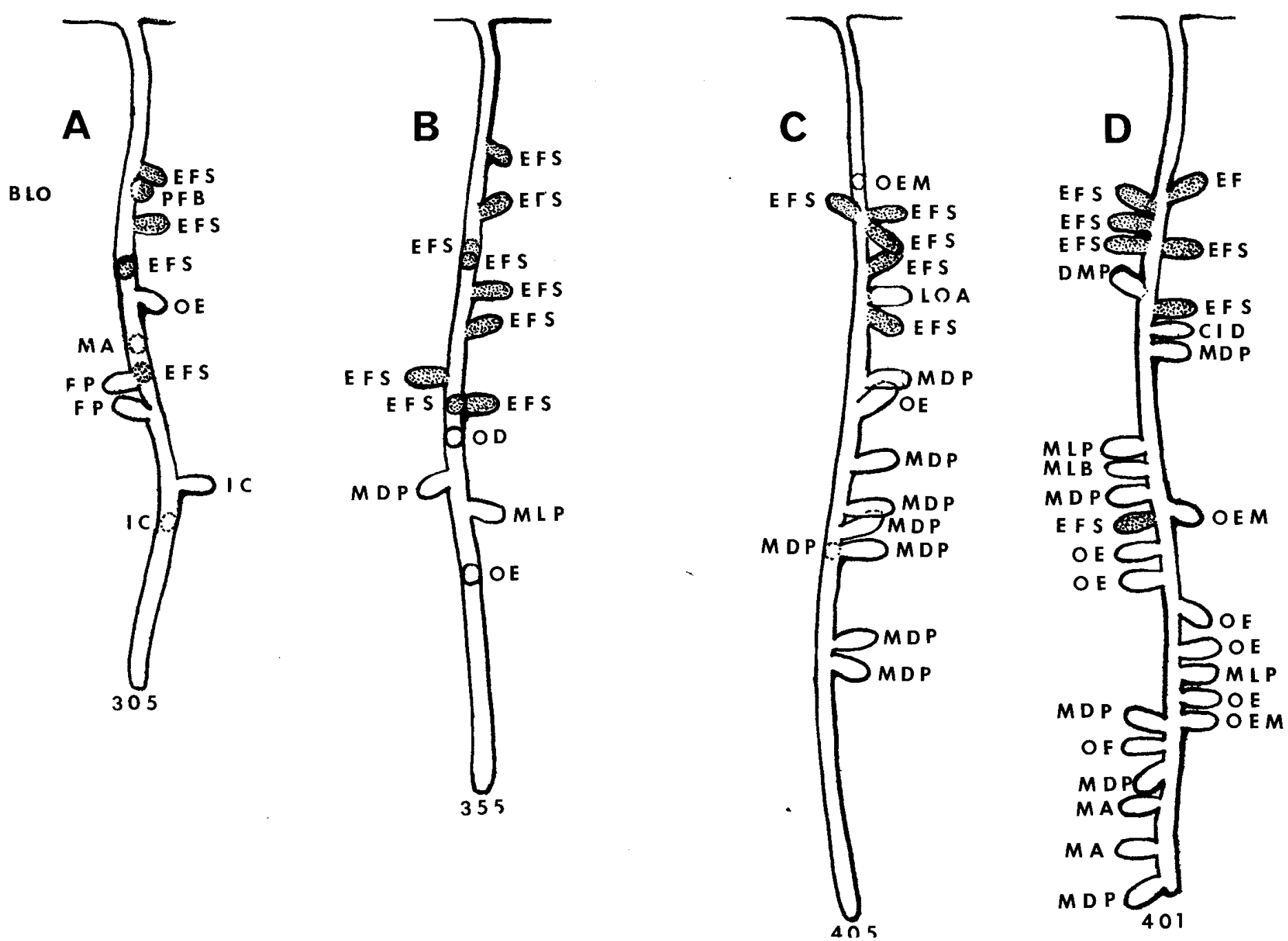

Figure $11 A-D .--$ Active social nests: $A$, Marked queen-guard and one daughter with pollen at entrance with no mature oocytes. Queen-guard had two mature oocytes. June 27, 1977. B, Marked queen-guard and one daughter newly emerged. Queen-guard with oosorption of two mature oocytes. July 14,1977 . $C$, Near end of season. Marked queen-guard dead in bottom of burrow. One daughter with immature oocytes and one newly energed male, August 4, 1977. $D$, At end of nesting season. The marked queen-guarded was not found, assumed dead. Two daughters without oocytes. August 16, 1979. 


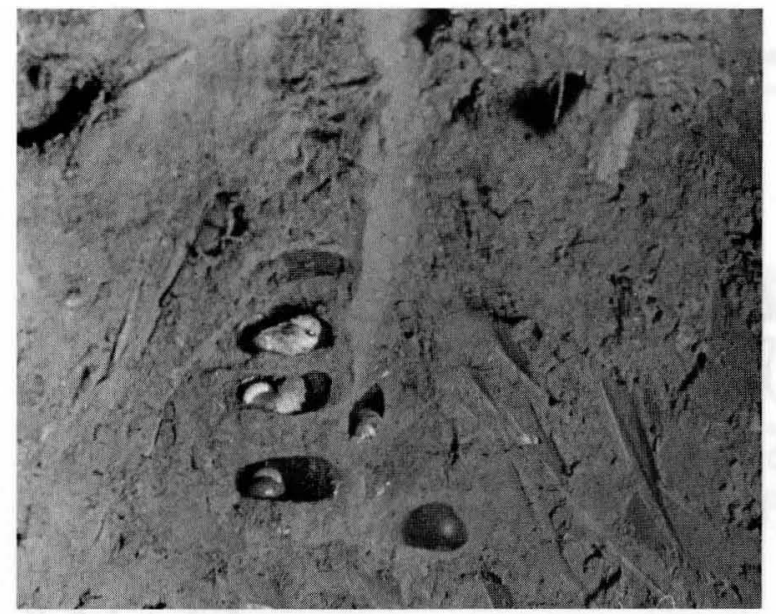

Figure 12.--First brood cells located 10 to $15 \mathrm{~cm}$ below surface.

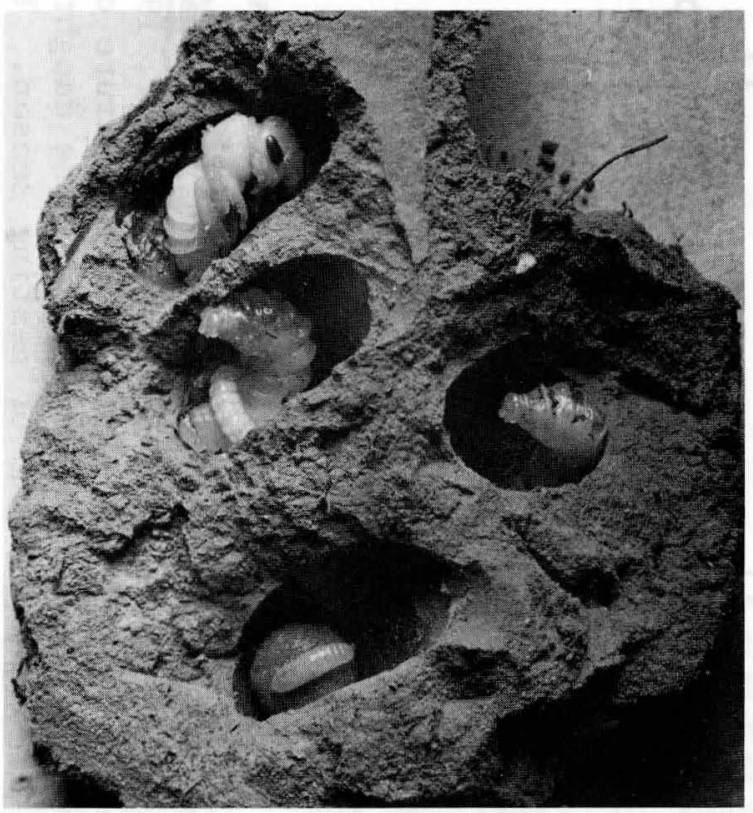

Figure 13.--A closeup of the first brood nest showing different stages of brood development--a female pupa, two prepupae ( $t$ he one on the left with a second stage bombyliid larva feeding on host), and a second instar larva feeding on pollen ball.

itself was 16 to $18 \mathrm{~mm}$ long, and 9 to $10 \mathrm{~mm}$ wide at the widest point. The cell wall was very delicate and smooth with the apical $2 / 3$ to $3 / 4$ waxed and dark brown (fig. 15). The waxed lining was quite reflective when first dissected from the soil but became lighter

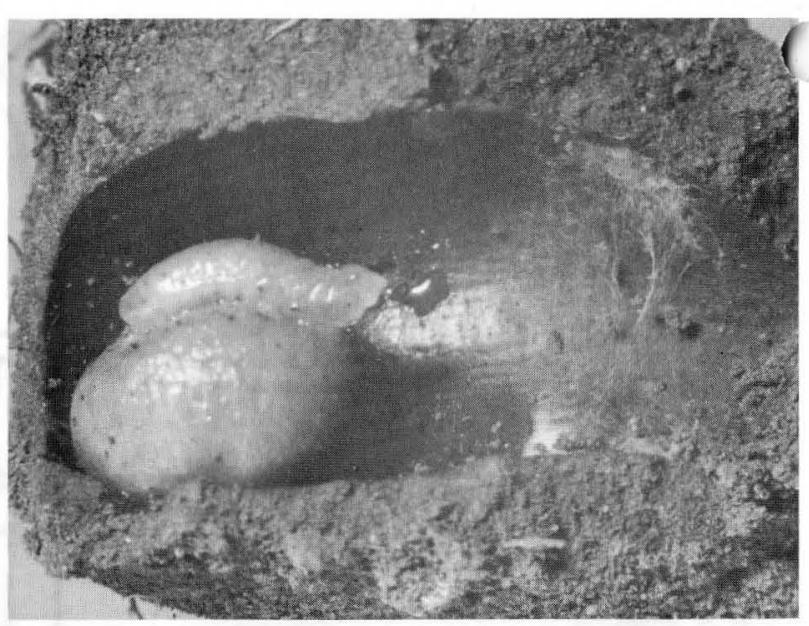

Figure 14.--Early third instar larva feeding on pollen ball.

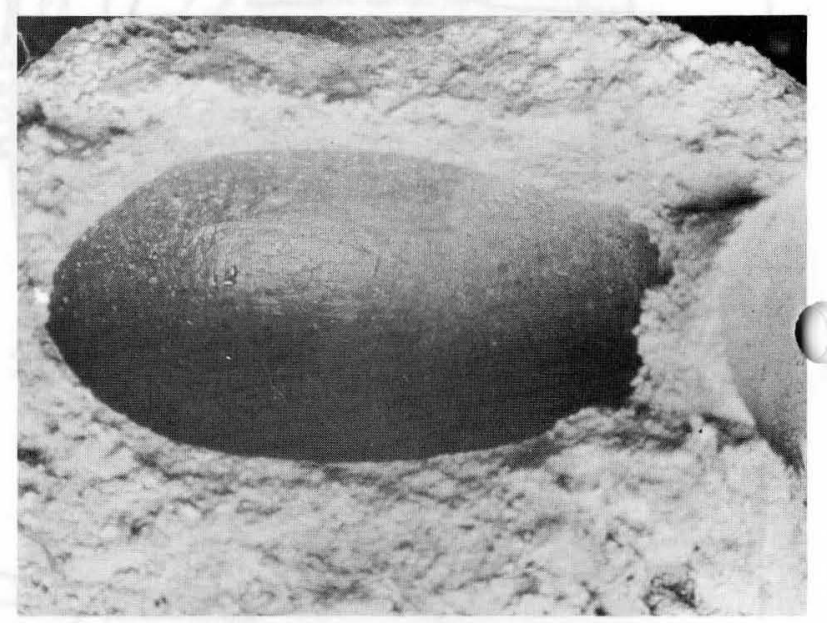

Figure 15.--Cell with apical $2 / 3$ to $3 / 4$ of cell waxed and entrance plug.

in color and almost invisible when exposed to the sun. The cells constructed by the workers during the social nesting stage were usually in a progressive sequence with each succeeding cell and group of cells at a deeper leve1.

The depth of cell placement appeared to be associated with moisture recession and heat penetration in midsummer. The more the moisture receded and heat penetrated into the soil, the deeper the bees constructed their brood cells. 
Two to four cells were frequently constructed at the same or almost the same level and formed a cloverleaflike pattern (fig. $11 \mathrm{C}$ ). More commonly, the depth of succeeding cells was measurably different, sometimes directly or almost directly in line with each other. Gaps between cell groups were probably caused by decreased bee activity during inclement weather.

\section{Provisions}

The bees provisioned their cells with pollen collected from several plant species growing in the Green Canyon area. From five to eight loads of pollen were necessary to provision a ce11. They fashioned the loads of rather dry pollen into a rough mass as each successive load was added (fig. 16). Next, they added nectar to the pollen and kneaded the rough mass into a slightly flattened sphere, somewhat flatter on top than on the bottom. The pollen balls were 5.5 to $6.5 \mathrm{~mm}$ in diameter and 4 to $5 \mathrm{~mm}$ high. The average weight of a pollen ball was $0.134 \mathrm{~g}$ with a range of 0.102 to $0.148 \mathrm{~g}$. The males were smaller than the females and probably got the smaller provisions.

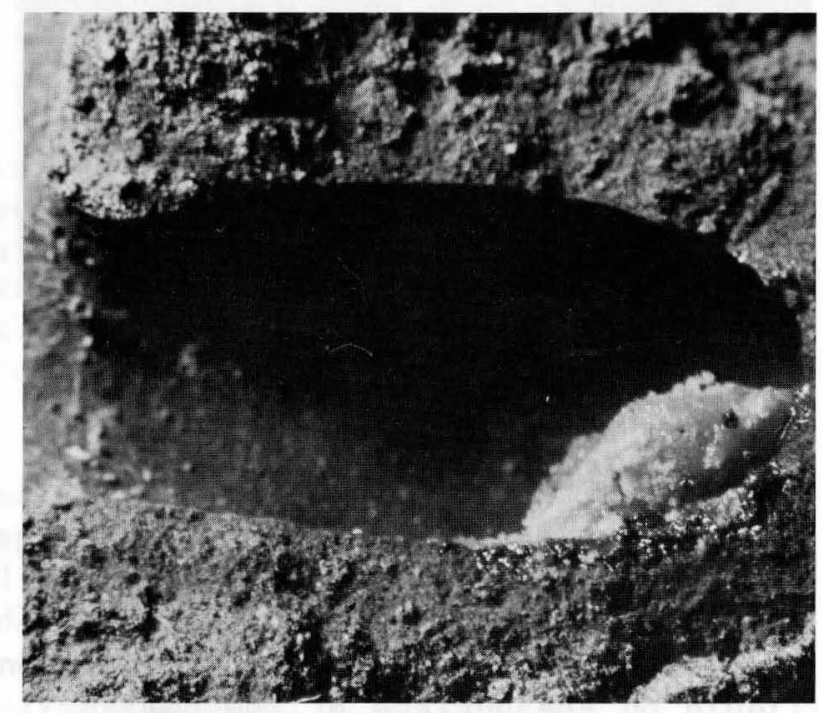

'Figure 16.--Open cell with one or two loads of pollen fashioned into a rough mass as each successive load is added.

\section{EGG-TO-ADULT DEVELOPMENT}

The egg was laid in a shallow trough on the top of the slightly flattened doughlike pollen ball parallel to the long axis of the cell. The egg, when first laid, was milky in color and arched over the pollen bal1. It was 4.2 to $4.5 \mathrm{~mm}$ long and about 1 to $1.2 \mathrm{~mm}$ in diameter. The posterior end of the egg was slightly embedded in the pollen ball while the anterior end rested on the pollen ball. The main body of the egg was arched above the pollen ball ( $\mathrm{fig}$. 17). The eggs of the first generation hatched in 3 to 5 days. As the embryo developed and appeared ready to hatch, the egg lost its arch and maintained full contact with the pollen ball. On the fourth day, the head and body segments were visible through the chorion (fig. 18). On the fifth day,

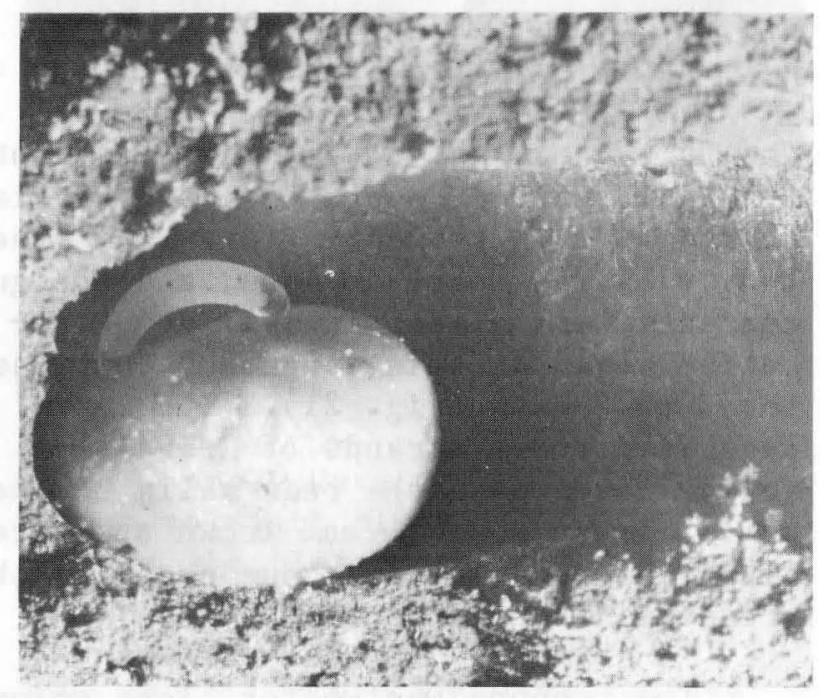

Figure 17.--Horizontal cell showing flattened lower side with pollen ball and egg. 


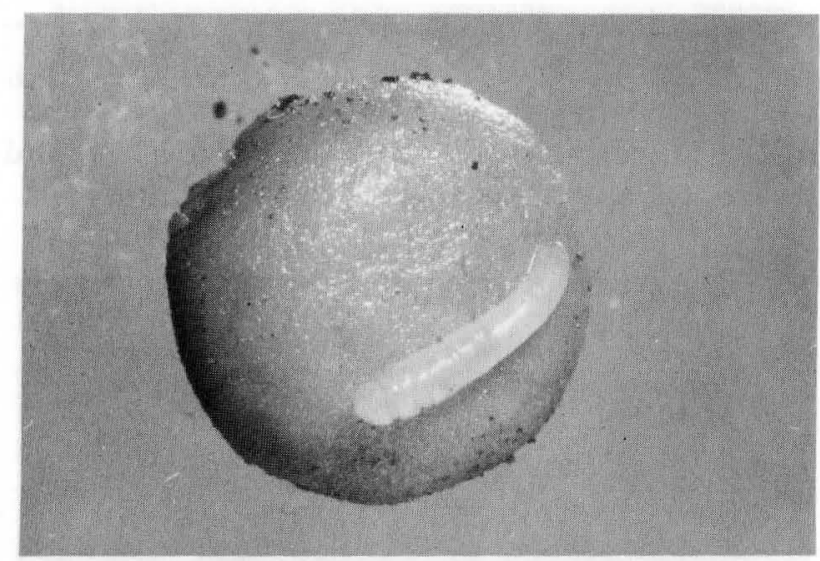

Figure 18.--The egg about ready to hatch is in full contact with pollen ba11. The head and body segments of the embryo are visible through the chorion.

the first instar larva was free of the chorion and appeared to be feeding upon liquid on the surface of the pollen ba11. The second instar larva consumed about one-third of the pollen bal1, and pollen was visible through the translucent integument. The third instar larva moved more rapidly forward, pivoting from side to side as it fed, flattening the pollen ball on top and toward the anterior end. The third instar larva fed for 2 to 3 days, consuming the remaining two-thirds of the pollen ball (fig. 19).

The full-grown larva was smooth, slightly moist, curved into a $\mathrm{C}$-shape, and lay on its side in the cell (fig. 20). The body wall was nearly opaque, and the gut contents were almost invisible. Defecation began at this stage and continued for 2 to 3 days (fig. 2l). The larva deposited ropey strands of brownishyellow feces upon the rear walls of the cell. These soon became brown and were flattened into a continuous smear by the pressure of the prepupa.

The prepupa was whiter, less shiny, and not as large as before defecation. It straightened out and had only a wideangled bend between the thorax and abdomen (fig. 22). It was still capable of movement when distur bed. The prepupal stage lasted 2 to 3 days.

The pupal stage lasted 7 to 10 days, and in this stage the male was distinguishable from the female (fig. 23 ) by its smaller size, more slender form, and longer antennae.

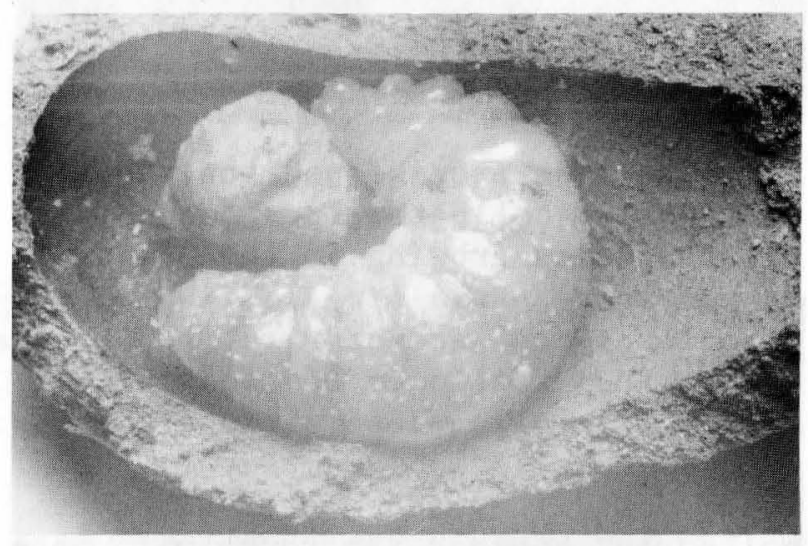

Figure 19.--The third instar larva comy pletes its feeding by moving forward and resting its dorsal side on the bottom of the cell while feeding upside down on the partially encircled pollen ba11 residue.

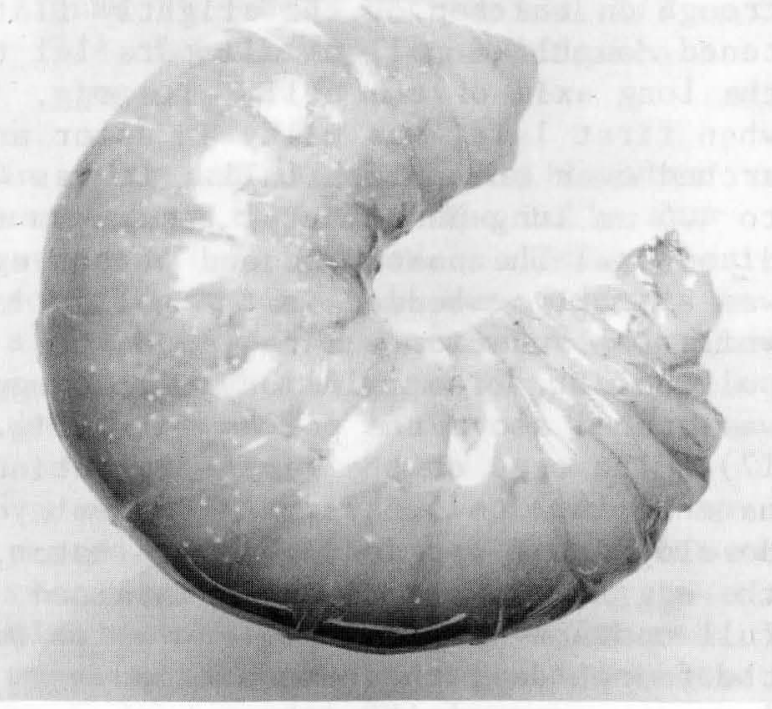

Figure 20.--Ful1-grown larva. 


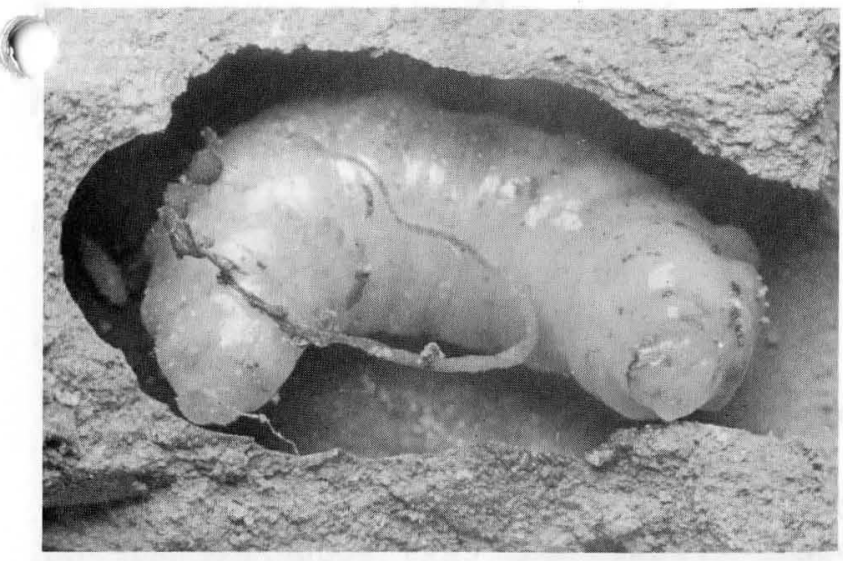

Figure 21.--Mature larva depositing feces in cell.

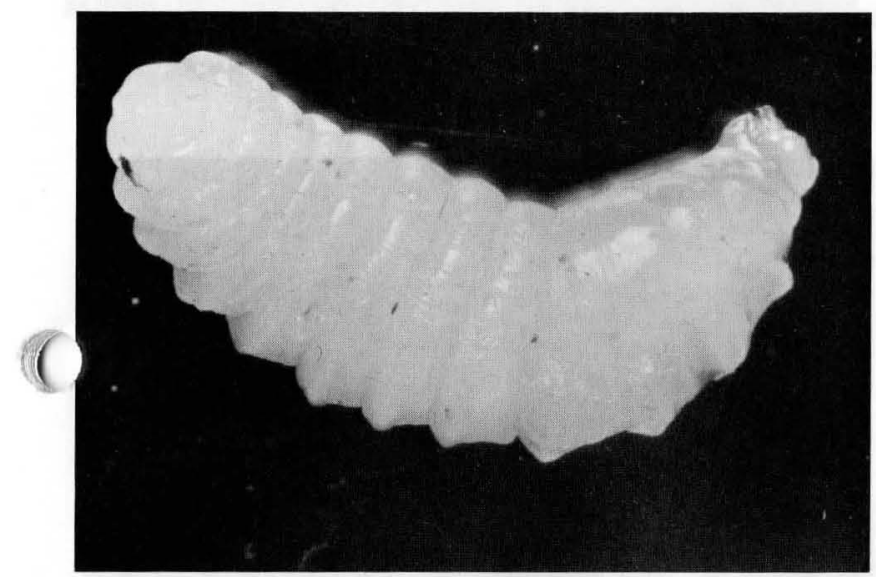

Figure 22.--Prepupa.

Rearing from egg to adult was difficult in the laboratory. The first and second instar larvae had a high mortality; the larvae often stopped feeding, assumed an unna- tural appearance, and had difficulty in molting. Third instar larvae, prepupae, and pupae, however, were readily reared to adulthood at room temperature and humidity. The approximate length of the brood was determined from rearing records and data from nest dissections.

In general, pollen balls were larger in the second generation brood stage, and the developmental period was about one week shorter. The faster rate of development was probably due to warmer soil temperatures during the second generation brood stage.

The immature stages took approximately the following times to develop: egg, 3 to 5 days; first instar larva, 1 to 3 days; second instar, 1 to 2 days; third instar, 2 to 3 days; defecation, 2 to 3 days; prepupa, 2 to 3 days; and pupa, 7 to 10 days.

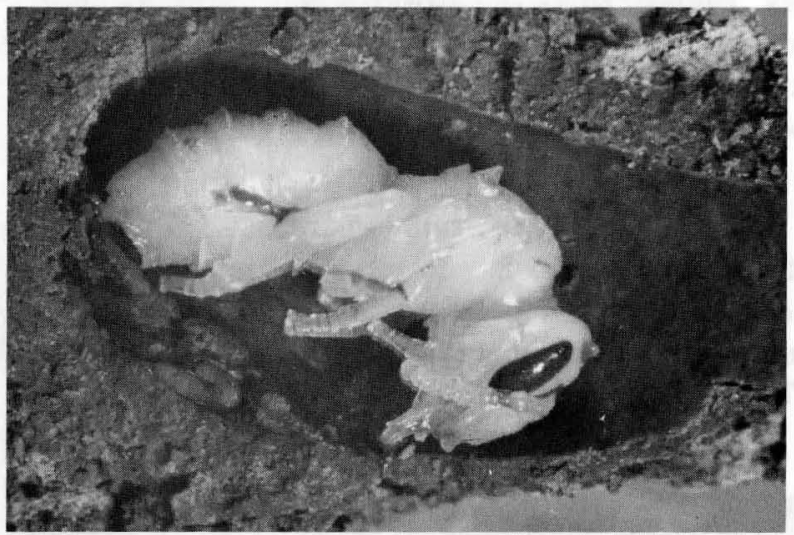

Figure 23.--Female pupa.

\section{DORMANCY AND HIBERNATION}

Mated females of $H$. farinosus left the nesting site to undergo dormancy. Most of all that survived late summer dormancy and subsequent hibernation returned to the original nesting site in the spring to establish their nests.

To determine whether any of the bees hibernated in the nesting sites, sites 3 and 4 were marked of $f$ into a series of eight plots 2 by $2 \mathrm{~m}$. Onehalf of the plots were then covered with clear lumite screen. The screens were placed over the nesting sites in late winter before the bees emerged from hibernation and were removed on May 11 after emergence. There was no sign that any bees had emerged or dug 
new burrows in the screen-covered plots. This confirms the findings of G. E. Bohart (personal communication) who erected a large field cage over the nesting site in the fall, removed the cage in the spring, and found that no bees had emerged or renested in the screened area.
Perhaps the bees seek some area that offers them the greatest amount of protection from the elements. Such an area might possibly be along the north face of the canyon floor where they would be least affected by temperature changes during the fall, winter, and early spring.

\section{PREDATORS AND PARASITES}

The robber fly (Mallophorina guidliana (Williston)) was the only predator observed attacking adult female $H$. farinosus on the wing. The fly killed the bee by inserting its sharp probosis through the thin membrane between the head and thorax and then extracting body fluids.

The cleptoparasitic bee (Sphecodes arvensiformis Cockere11) was seen flying over the nesting sites and entering burrows of $H$. farinosus as we11 as those of $H$. I igatus Say and $H$. rubicundus Christ. Sphecodes is known to destroy the host egg and replace it with her own (fig. 24).

The larva of the inquilinous bee flies Bombylius major L. and B. albicapillus Leow were observed as parasites on the larvae of $H$. farinosus. The adult fly hovered over the nest of

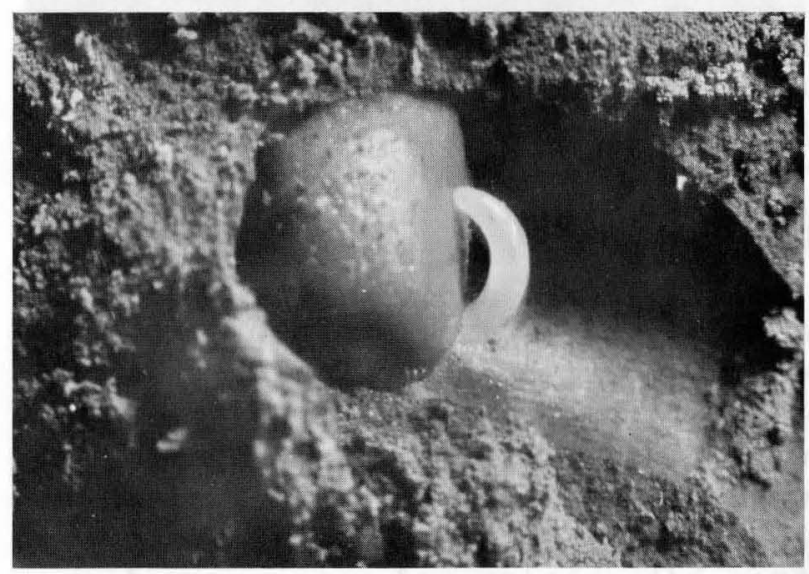

Figure 24.--Sphecodes arvensiformis egg on host pollen ball. the host bee and hurled eggs into its open burrow. The eggs soon hatched and the first instar larvae crawled or were carried into the brood cells. Figure 25 shows the first instar bombyliid larva examining the host egg. The bombyliid larva then waited until the bee larva reached the prepupal stage

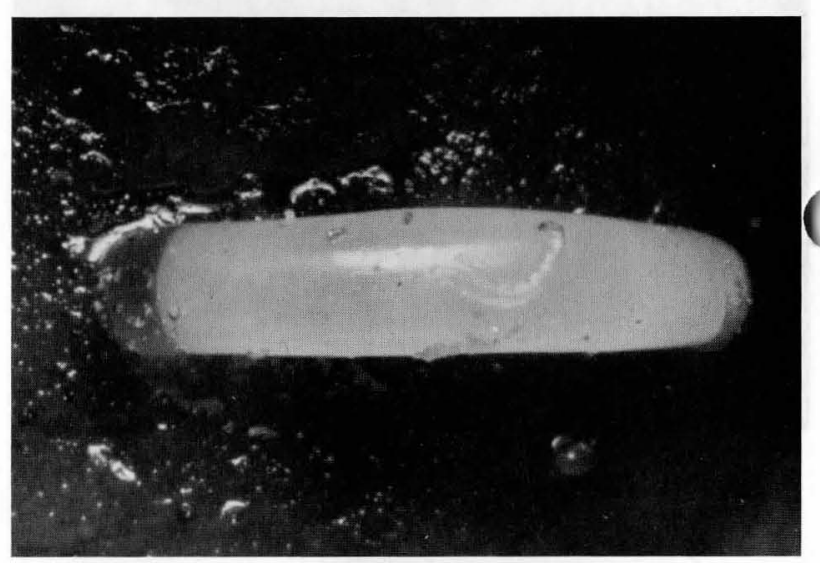

Figure 25.--First instar larva of bombyliid on host egg.

before attaching itself to the host and beginning to feed (fig. 13), consuning one (and sometimes two) bee larvae before migrating to its own overwintering cell ( $f i g \cdot 26$ ). The adult usually emerged the following spring as evidenced by the presence of the pupa and pupal exuviae in the host nesting site (fig. 27 and 28).

Leucophora obtusa (Zetterstedt), an anthomyid fly, was a fairly conspicuous, gregarious predator-parasite around $H$. farinosus nests; however, only a few host cells containing im- 
mature stages of the fly were found fig. 29). The flies entered the host nest entrance and laid their eggs near the mouth of the burrow.

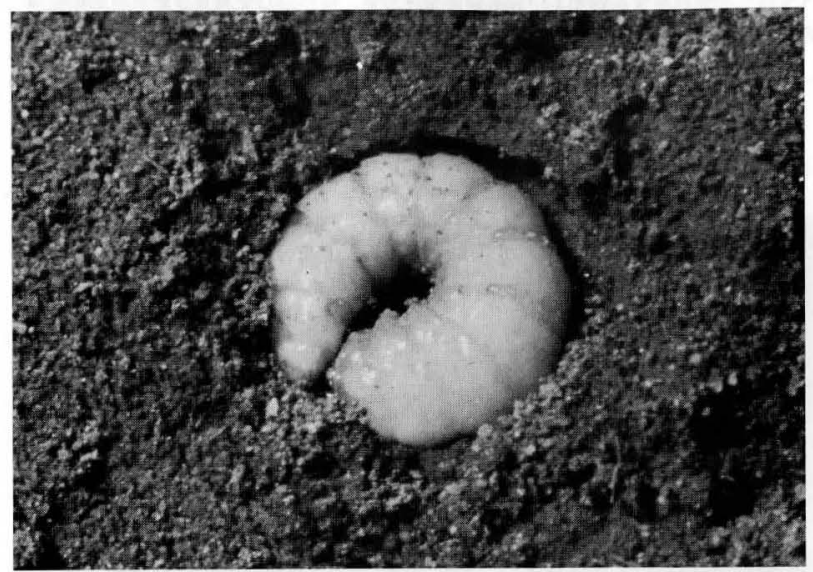

Figure 26.--Bombyliid prepupa in overwintering cell.

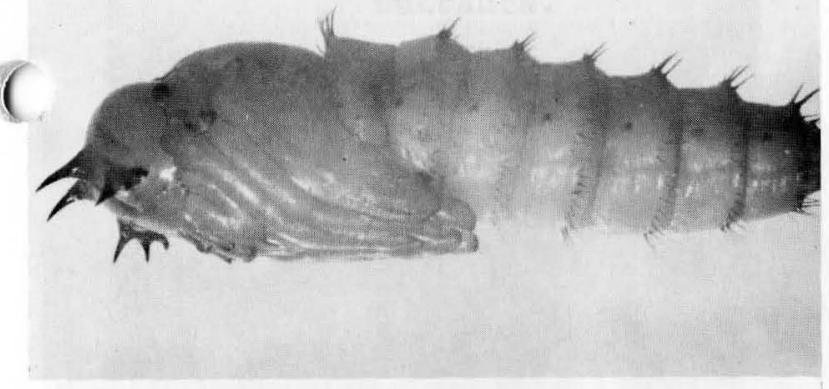

Figure 27..--Bombyliid pupa.

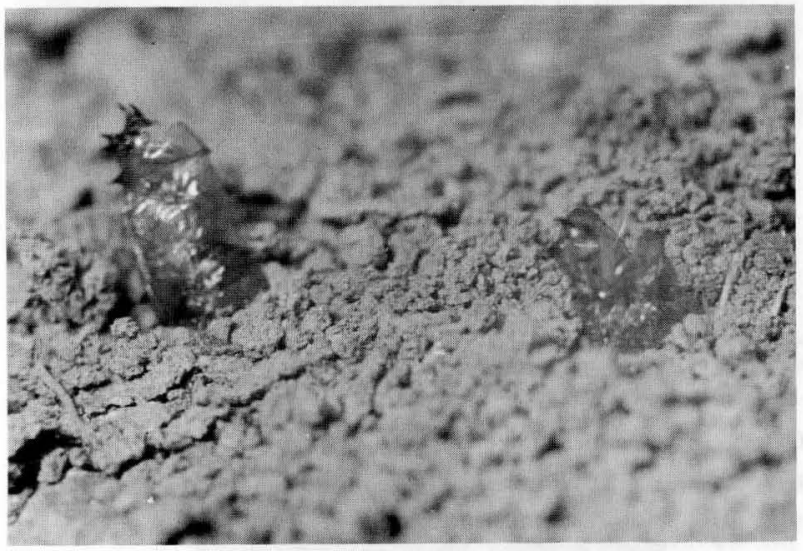

Figure 28.--Bombyliid pupal exuviae in host nesting site.
The first instar larvae attached themselves to hairs on the bee's body and were transported to the cell by the bee. The rnaggots spoiled the pollen, and the first instar bee larva died. Occasionally, the bee larva was mature enough (usually a second instar) to feed rapidly enough to starve the fly maggots (fig. 30).

Minute ants, probably of the genus Tapinoma sp., occasionally invaded the sealed cell of the host through the back of the cell and consumed the cell contents. They were too small to pose any threat to the guard bee and were never seen in the nest burrow.

\section{An anoetid mite (Histiogaster} sp.) was often seen on the bee larvae, pupae, and adults (fig. 31). In the

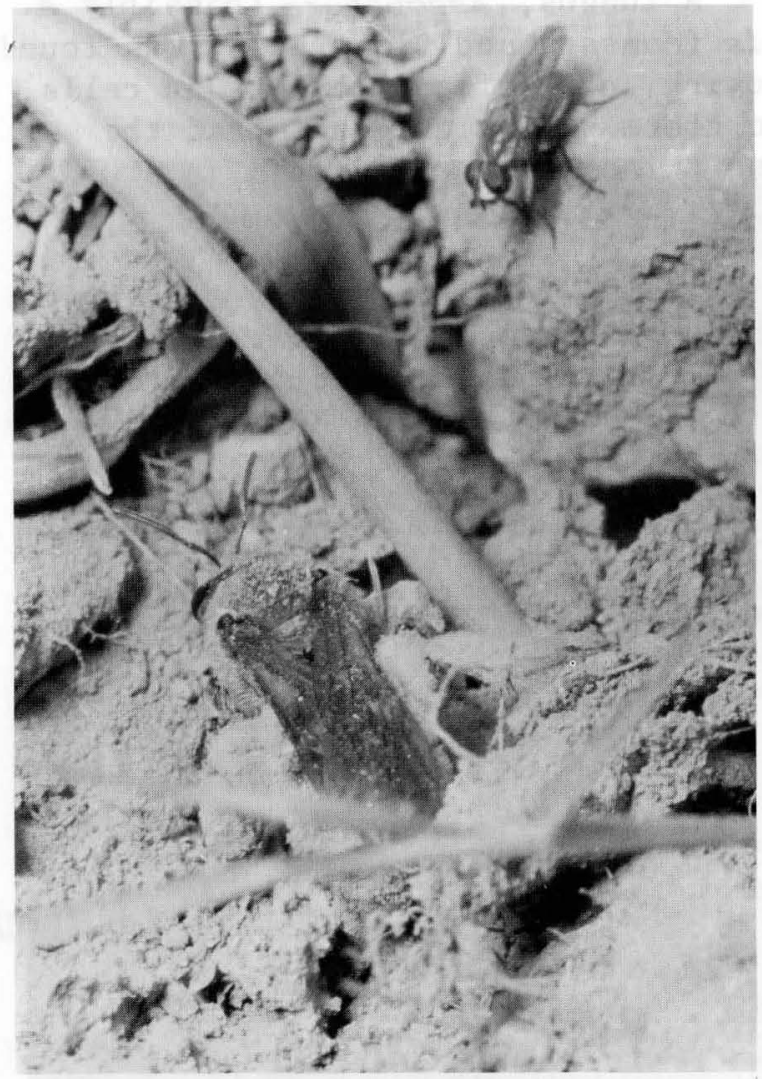

Figure 29.--Leucophora obtusa adult female watching host bee at nest entrance. 


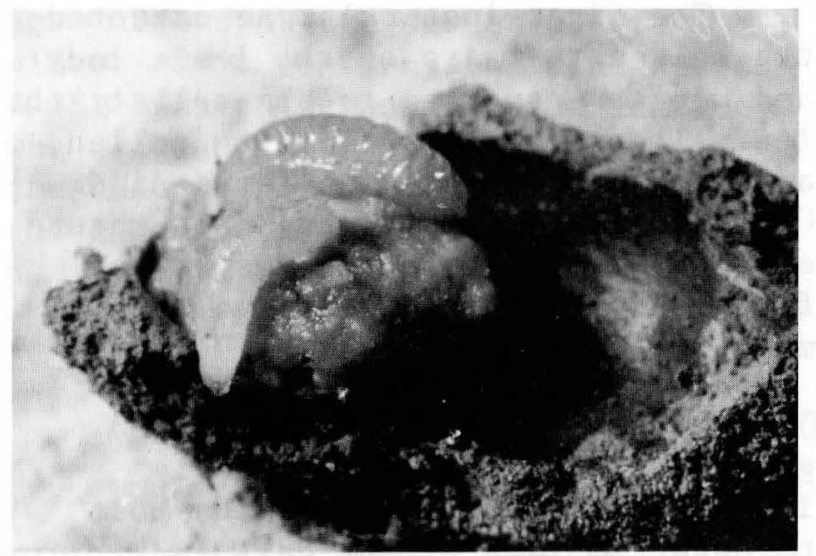

Figure 30.--Maggots of Leucophora obtusa on pollen ball with second instar host larva.

cells, a pyemotid mite (Trochometridium tribulatum Cross) was of ten found associated with mold at the bottom of the cell (fig. 32).

A fungus, Ascophaera (possibly $A$. apis (Maassen and Claussen)), was found growing in the fecal pellets in cells, but there was no evidence that the fungus harmed the bee larva in any way (fig. 32).

A meloid beetle (Nemognatha lutea LeConte) was found ovipositing on gumplant (Grindel ia squarrosa (Pursh) Dunal.) where the bees apparently acquired the $N$. Iutea triungulinids.

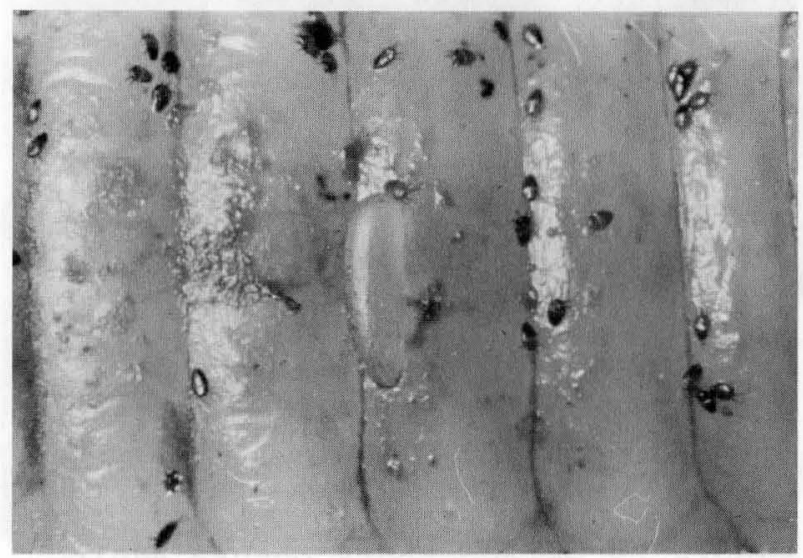

Figure 31.--Anoetid mites on prepupa of bee; also, egg of Dasymutilla.
Several N. Iutea prepupae were found in the cells of $H$. farinosus ( $\mathrm{fig} \cdot 33$ )

I also collected Meloe sp.

(Coleoptera: Meloidae) and Dasymutilla sp. (Hymenoptera: Mutillidae) in the

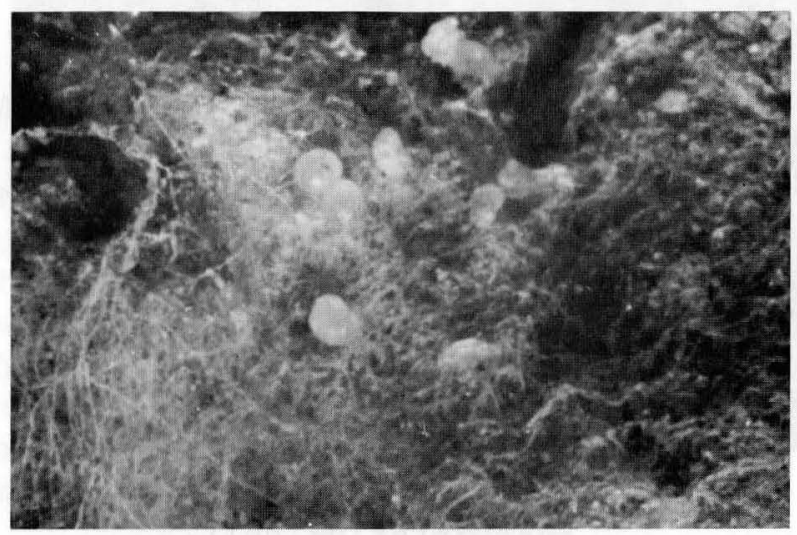

Figure 32.--Pyemotid mites on mold growing on the fecal pellets in the cell.

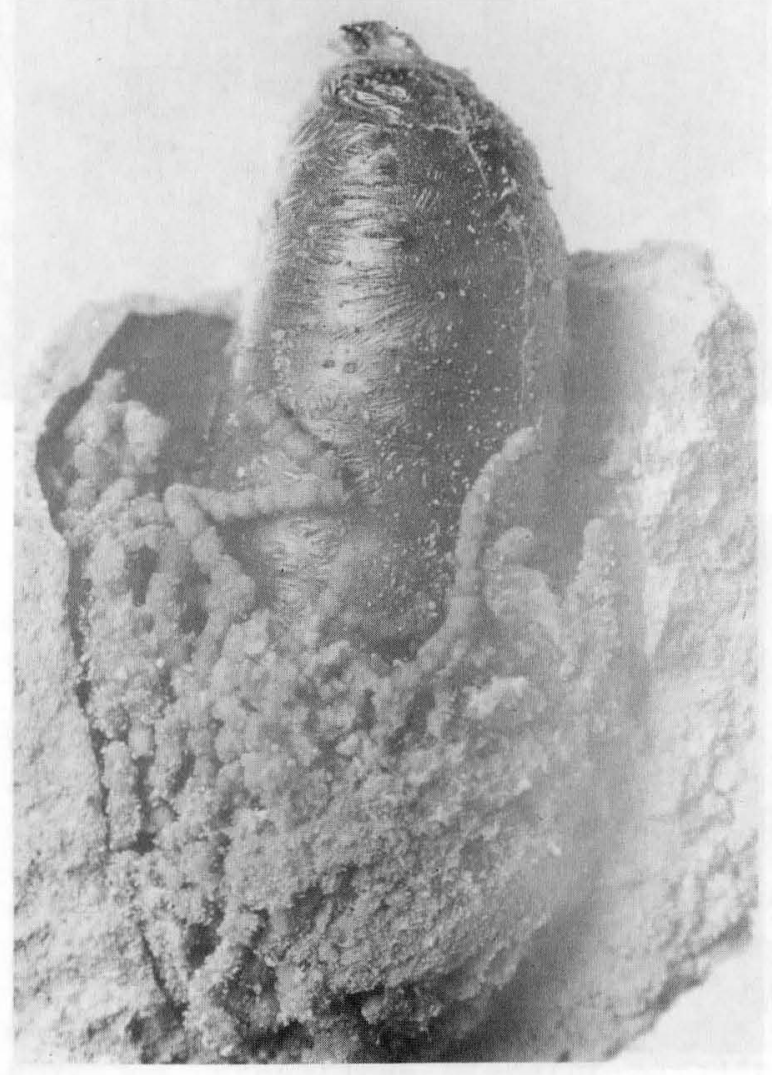

Figure 33.--Nemognatha puparium in host cell. 
nesting sites of $H$. farinosus but did .ot find any immatures in nest dissection ( $\mathrm{fig} \cdot 34$ ). In an earlier study with G. E. Bohart (unpublished communication), we found immatures of Dasymutilla (figs. 31 and 35) and larvae of the Rhipiphorid beetle, Rhipiphorus, feeding on prepupae of $H$.

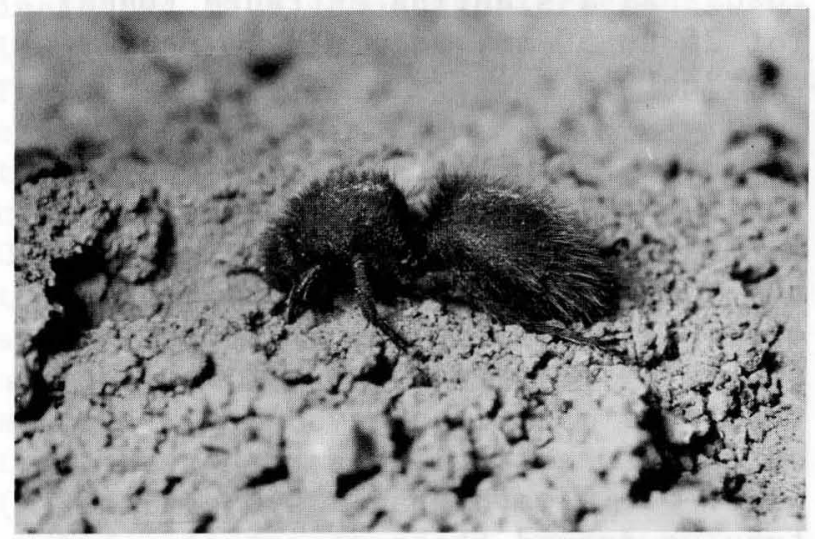

Figure 34.--Dasymutilla at host nest entrance.

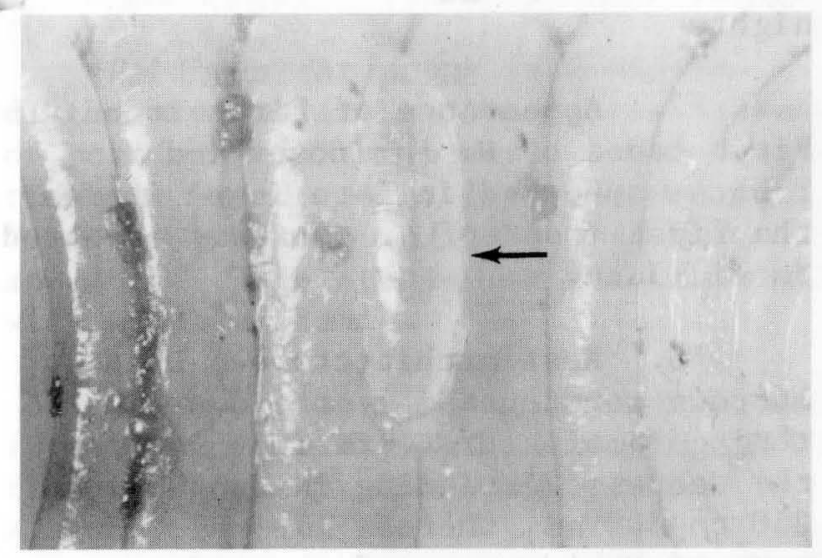

Figure 35.--First instar larva of Dasymutilla (arrow) feeding on prepupa of host. farinosus (fig. 36). We also found first-stage larvae of Strepsiptera, probably Stylops sp., just under the integument of the first instar host larva (fig. 37); however, Strepsiptera apparently did not develop on this host.

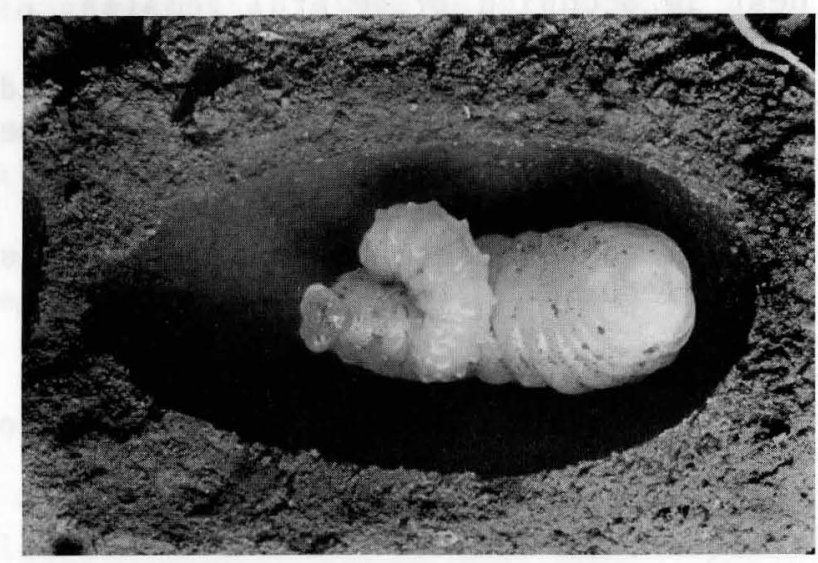

Figure 36.--Rhipiphorus larva feeding on prepupa of host.

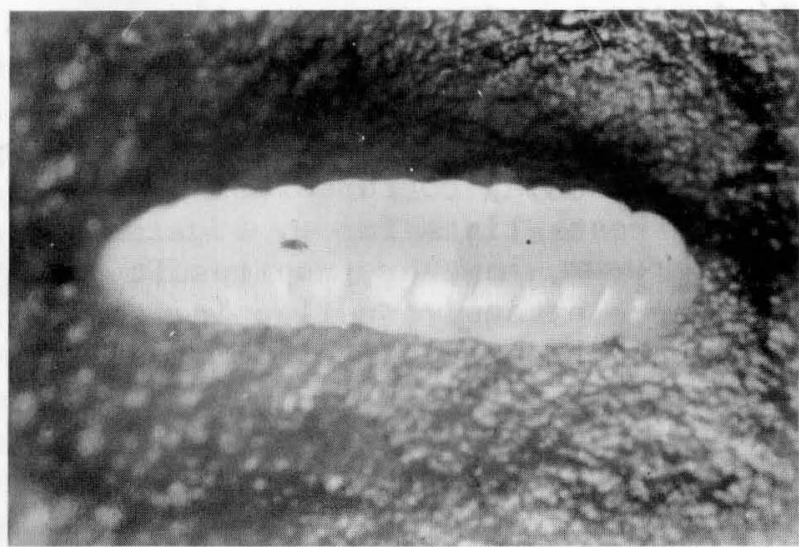

Figure 37.--First instar larva of Strepsiptera under skin of first instar host larva.

\section{DISCUSSION}

Biological observations have been published on only about 6 to 10 percent of the species belonging to the family Halictidae occurring in America, north of Mexico. With few exceptions, such , bservations have been brief notes dealing with singular incidents such as nest construction, adult behavior, or flower visitation.

Halictine bees differ radically in their modes of life. Many species 
are solitary forms in which each female is responsible for the construction and provisioning of her own nest. This behavior was observed in Evylaeus galpinsiae Cockerell by Bohart and Youssef (1976). Other species such as certain Lasioglossum, construct communal nests with a common entrance. Each nest is occupied by several females each of which constructs and maintains her own series of cells without the aid of other females. These nests continue to expand during the nesting season. Other species are more social and develop a worker caste as in some species of Hal ictus.

The biology of Hal ictus farinosus appears to differ in the following respects from the species of North American Halictus reported in the 1iterature:

\section{Host range of flowering} plants from which the bees have been recorded. H. farinosus has been recorded from 43 species of plants from 14 families. Chandler (1955) reported 200 species from 41 families for $H$. 1 igatus Say; Dolphin (1966) recorded 165 species from 40 families for Hal ictus (Seladonia) confusus Smith. The larger hosts 1 ists for $H$. I igatus and $H$ - confusus, however, may result simply from more extensive collecting and searches through collected material.

2. Place of hibernation. $H$. farinosus left the nesting site to hibernate. Chandler (1955) reported that $H$. I igatus hibernated in old nests, and Dolphin (1966) reported that H. confusus constructed new burrows in the nesting site in which to hibernate.

\section{Emergence date of females}

from hibernation. H. farinosus emerged on April 8; Chandler (1955) reported that $H$. I igatus emerged on May 3; and Dolphin (1966) reported that $H$. confusus emerged on April 19.

\section{The length of "resting"}

period after nest founding and prior to provisioning. H. farinosus rested for 2 to 3 weeks, H. I igatus about 10 days to 2 weeks, while $H$. confusus rested for about 2 to $2 \frac{1}{2}$ weeks.

\section{Nest tunnels. H. fari-} nosus and $H$. I igatus constructed near$1 y$ vertical burrows, whereas $H$. confusus had a slanting entrance tunnel for 25 to $50 \mathrm{~mm}$, adjoining a nearly vertical burrow.

6. Tumulus. The tumulus for $H$. farinosus was symmetrical with a horizontal entrance tunnel beneath the tumulus which was always left open. A similar tumulus turret is formed by Nomia triangul ifera except that this species always plugs the entrance when it leaves or enters the nest. H. I igatus had a symmetrical tumulus around the nest entrance and plugged the entrance at night. $H$. confusus formed a semicircular mound some distance in front of the nest entrance and plugged the entrance at night.

\section{Appearance of first brood.} First brood of $H$. farinosus and $H$. I igatus appeared in late June, whereas the first brood of $H$. confusus appeared in mid-June.

\section{Nest architecture. Main} burrows constructed by the overwintering females of $H$. farinosus were the deepest, extending in depth from 250 to $300 \mathrm{~mm}$, whereas the main burrows of $H$. $I$ igatus and $H$. confusus ranged from 100 to $150 \mathrm{~mm}$ in depth.

\section{Length of foraging trips.} Foraging trips for $H$. farinosus varied in length from 15 to 235 min with an average of $131 \mathrm{~min}$, and those of $H$. 1 igatus ranged from 20 to $45 \mathrm{~min}$ with an average of $30 \mathrm{~min}$.

10. Colony development. $H$. farinosus produced small colonies. The first brood of two to five workerd 
(11 females) produced an average of A cells; the second brood cycle produced both males and females. The females constituted the overwintering queens for the following year. Chandler (1955) reported three brood cycles for $H$. I igatus with the first brood cycle about the same size as that in $H$. farinosus. The nest population increased in a geometrical ratio as long as only workers were produced. The second brood in most nests were generally all females, further increasing the size of the nest. The third brood cycle contained both males and females. Once males and queens were produced, the colony diminished in size and strength since these bees contributed nothing to the economy of the colony. $H$. confusus produced colonies about the size of $H$. Iigatus. Dolphin (1966) reported that males were present in all broods of $H$. confusus.
Males were scarce in the first brood, became more common as the season progressed, and constituted 42 percent of the colony population. Males mated with females throughout the summer.

Further research is needed in the biology and behavior of $\mathrm{H}$. farinosus to answer the following:

\section{Do al1 the first progeny} females of the queen become workers in the nest?

2. Does the queen lay any male eggs?

3. Where do the mated females overwinter?

4. Do all recently mated females leave the nest and go into dormancy?

\section{SUMMARY}

Hal ictus farinosus is a widely distributed halictine bee in the States or portions of States west of the Continental Divide. The life history of H. farinosus was studied during 1976 and 1977. This species is a social bee with a worker caste.

The topography of the nesting site is generally in dry mesic canyons, on flat or slightly sloping ground sparsely covered with vegetation. The nests may be singly or gregariously situated, a result of site utilization rather than any benefits derived from such groupings.

The species is one of a number of halictine bees that leave the nesting site entirely to hibernate. Most of them return to the nesting site in the spring of the following year. In 1977, the first queen emerged on April 8 . Then the bees emerged from hibernation, rey $v$ isited Lomatium grayi for nectar and pollen to satisfy their own nutritional requirements. They began $\mathrm{dig}-$ ging the main burrows in the nesting sites and remained in the burrows for a number of days without further activity. Bee activity, nest construction, and larval development were correlated with the sequence of seasonal events. During the early stage of nest construction, foraging and pro$\mathrm{v}$ isioning of cells, laying eggs, and guarding the nest were the same as for a solitary female of a nonsocial species.

The first female progeny appeared in late June and early July and became active as workers in the parental nests. As workers, they enlarged the nest, constructed and provisioned cells, and fashioned pollen balls on which the queen laid eggs.

The second progeny of bees emerged in mid-August and contained both males 
and females. The second female progeny did not become active as workers in the parental nest but left the nesting area to void wastes, feed, mate, and hibernate.

The number of active nests declined with the advance of the season. The decline in number of nests was due partly to the death of the overwintering queen after digging their main burrows. Other queens died before the first brood emerged, and the bees abandoned the nest after emergence. The decline in active nests was similar at other nesting sites.

Although $H$. farinosus is polylectic, having been recorded from 43 species of plants, the principal flowers visited in the areas studied were Bal samorhize sagittata, Lomatium grayi, Mel itotus al ba, Phacel ia hastata, Prunus virginiana, and Taraxacum officinale.

Nests constructed were vertical, with a single main shaft and a symmetrical tumulus-turret pattern with the entrance always left open and numerous very short horizontal laterals, each ending in a horizontal cell. The cell cap is composed of a series of concentric spiral rings of soil visible on the inside of the cell cap but smooth and flush with the main burrow wall. The horizontal cell constructed by the queen was 16 to $18 \mathrm{~mm}$ long, arched and 9 to $10 \mathrm{~mm}$ at the maximum width, flattened on the lower side, the cap was 3 to $5 \mathrm{~mm}$ thick at the lal eral entrance. The cell wall was very delicate and smoothed, and the apical $2 / 3$ to $3 / 4$ of the cell was waxed and dark brown. The cells constructed by the workers were similar and were in progressive sequence with each group constructed at a slightly deeper level.

About five to eight loads of rather dry pollen were necessary to provision a cell. Nectar was then added to the pollen and kneaded into a sphere, slightly flatter on top than on the bottom. The egg was laid in a groove on the top of the doughlike pollen ball, parallel to the long axis of the cell. When the egg was first laid, it was milky white in color and arched over the pollen ball. The development of the immature stages took approximately the following times to develop: Egg, 3 to 5 days; first instar larva, 1 to 3 days; second instar, 1 to 2 days; third instar, 2 to 3 days; defecation, 2 to 3 days; prepupa, 5 to 7 days; and pupa, 7 to 10 days.

Organisms found in the cells (other than Hal ictus) included a cleptoparasitic bee larva and several phorid fly larvae (feeding on pollen), microants, and mites (in cells and on pollen), and immatures of bee flies, mutillid, and a species of Rhipophorus beetles (feeding on host larvae).

\section{LITERATURE CITED}

(1) Ashmead, W. H. 1903. A new Paranomia from British Columbia. Canadian Entomologist $35: 243$.

(2) Bohart, G. E.

1952. Pollination by native insects. In Insects U.S. Department of Agriculture, Yearbook of Agriculture 1952, p. 107-121. 
(3) Bohart, G. E., and W. P. Nye.

1960. Insect pollinators of carrots in Utah. Utah Agricultural Experimentation Station Bulletin No. 419.

(4) Bohart, G. E.; W. P. Nye, and L. R. Hawt horn.

1970. Onion pollination as affected by different levels of pollinator activity. Utah Agricultural Experiment Station Bulletin No. 482.

(5) Bohart, G. E., and Nabill N. Youssef.

1976. The biology and behavior of Evylaeus gal pinsiae Cockerell. The Wasmann Journal of Biology 34(2):185-234.

(6) Chandler, L.

1955. Ecological life history of Hal ictus $\left(H_{\bullet}\right)$ ligatus Say with notes on related species. Unpublished Ph. D. Thesis, Purdue University Library, Lafayette, Ind.

(7) Crawford, J. C.

1902. Hal ictus montanus. Canadian Entomologist 34:234.

(3) Dolphin, R. E.

1966. The ecological life history of Hal ictus (Seladonia) confusus

Smith. Unpublished Ph.D. Thesis, Purdue University Library,

Lafayette, Ind.

(9) Hungerford, H. B., and Francis X. Williams.

1912. Biological notes on some Hymenoptera. Entomological News 23:241.

(10) Kirkton, R. M.

1968. Biosystematic analys is of variation of Hal ictus I igatus Say.

Unpublished Ph.D. Thesis, Purdue University Library, Lafayette, Ind.

(11) Litte, Marcia.

1977. Aspects of the social biology of the bee Hal ictus I igatus in New York State (Hymenoptera: Halictidae). Insect Sociaux 24(1):9-36.

(12) Michener, C. D., and F. D. Bennett.

1977. (On H. I igatus.) University of Kansas Science Bulletin No. 51, p. 233-260.

(13) Roberts, R. B.

1973. Bees of Northwestern America: Hal ictus. Oregon Agricultural

Experiment Station Bulletin No. 126.

(14) Robertson, C.

1928. Flowers and insects. Lists of visitors of 453 flowers. Science

Press. Lancaster, Pa. $221 \mathrm{p}$.

(15) Sandhouse, Grace A.

1941. The American bees of the subgenus Hal ictus. Entomologica Americana $21: 23-39$.

(16) Stephen, W. P., G. E. Bohart, and P. F. Torchio.

1969. The biology and external morphology of bees with a synops is of the genera of Northwestern America. Oregon Agricultural Experiment Station, Corvallis. 140 p.

(17) Vachal, J.

1904. Hal ictus denticul us female and $H$. procerus male. Social Science Historical Archives, Correze Bulletin No. 26-469. 


\section{Key to Symbols Used in Illustrations}

AF Adult female in cell, recently emerged.

BL Bombyliid larva in overwintering cel1.

CIP Cell closed with incomplete provisions.

DAF Dead adult female.

DMP Dead male pupa.

EFS Emerged and cell filled with soil, current season.

DL Diseased larva.

EP Egg on pollen bal1.

FP Female pupa.

IC Incomplete cell. Construction is recent and incomplete.

LAF Live adult female.

LL Large larva.

LOA Leucophora obtusa adult.

LOL Leucophora obtusa larva.

MA Adult male in cell, recently emerged.

MDP Male, dark-colored pupa.

ML Medium-size larva.

MLB Medium-size bombyliid larva feeding on host.

MLP Male, light-colored pupa.

OD Open depleted cell; cell opened by ants and contents being eaten.

OE Adult emerged and cell open.

OEM Adu1t emerged, cell open; fungus hyphae on fecal deposit.

OIP Cell open with incomplete provisions.

PFB Partially filled cell containing remains of host fed upon by bombyliid larva.

SB Small bombyliid larva feeding on host.

SL Sma11 larva.

\section{Glossary}

Anoetid

Chorion

Cleptoparasitic

Entomophilous

Halictine

Immatures

Inquiline
Mites in the family Anoetidae are commonly referred to as anoef mites.

Outer covering of egg.

A thief, thievish, stealing the provisions from another.

Insect loving; applied to plants especially adapted for pollination by insects.

Bees in the subfamily Halictini (Halictidae) are commonly referred to as halictine bees.

Larval forms of insects.

An associate. An insect that habitually lives in the nest of another species. 
( tegument The outer covering or cuticle of the insect body.

Meloid Blister-beetles of the family Meloidae (Coleoptera) are commonly referred to as meloid beetles.

Mesic Medium dry canyons.

Polylectic Collecting food (pollen and nectar) from a number of plant species.

\section{Pyemotid}

Mites in the family Pyemotidae are commonly referred to as pyemotid mites.

Tumulus

Mound of soil made in digging the main burrow. 